\title{
Epitope-resolved serology test differentiates the clinical outcome of COVID-19 and identifies defects in antibody response in SARS-CoV-2 variants
}

Courtney Voss ${ }^{1,9}$, Sally Esmail ${ }^{1,9}$, Xuguang Liu ${ }^{1}$, Michael J. Knauer ${ }^{2}$, Suzanne Ackloo ${ }^{3}$, Tomonori Kaneko $^{1}$, Lori Lowes ${ }^{2}$, Peter Stogios ${ }^{4}$, Almagul Seitova ${ }^{3}$, Ashley Hutchinson ${ }^{3}$, Farhad Yusifov ${ }^{3}$, Tatiana Skarina ${ }^{4}$, Elena Evdokimova ${ }^{4}$, Peter Loppnau ${ }^{4}$, Pegah Ghiabi ${ }^{4}$, Taraneh Haijian ${ }^{4}$, Shanshan Zhong ${ }^{1}$, Husam Abdoh², Benjamin D. Hedley², Vipin Bhayana ${ }^{2}$, Claudio M. Martin ${ }^{5,6}$, Marat Slessarev $^{5,6}$, Benjamin Chin-Yee ${ }^{7}$, Douglas D. Fraser ${ }^{5,6,8}$, Ian Chin-Yee ${ }^{2}$ and Shawn S-C. Li ${ }^{*}$

Department of ${ }^{1}$ Biochemistry, ${ }^{2}$ Pathology and Laboratory Medicine, ${ }^{5}$ Medicine, ${ }^{8}$ Pediatrics and ${ }^{7}$ Divison of Hematology, Western University, London, Ontario N6G 2V4 and ${ }^{6}$ London Health Sciences Centre, 800 Commissioners Rd E, London, Ontario N6A 5W9, Canada;

${ }^{3}$ Structural Genomics Consortium and ${ }^{4}$ Department of Chemical Engineering and Applied Chemistry, University of Toronto, 101 College St, MaRS South Tower, Suite 700, Toronto, Ontario M5G 1L7, Canada.

${ }^{9}$ These authors contributed equally to this work.

*Corresponding author: sli@uwo.ca 
medRxiv preprint doi: https://doi.org/10.1101/2021.03.16.21253716; this version posted March 20, 2021. The copyright holder for this preprint (which was not certified by peer review) is the author/funder, who has granted medRxiv a license to display the preprint in perpetuity.

All rights reserved. No reuse allowed without permission.

BACKGROUND. The role of humoral immunity in the coronavirus disease 2019 (COVID-19) is not fully understood owing, in large part, to the complexity of antibodies produced in response to the SARS-CoV-2 infection. There is a pressing need for serology tests to assess patient-specific antibody response and predict clinical outcome.

METHODS. Using SARS-CoV-2 proteome and peptide microarrays, we screened 146 COVID-19 patients plasma samples to identify antigens and epitopes. This enabled us to develop a master epitope array and an epitope-specific agglutination assay to gauge antibody responses systematically and with high resolution.

RESULTS. We identified 54 linear epitopes from the Spike (S) and Nucleocapsid (N) protein and showed that epitopes enabled higher resolution antibody profiling than protein antigens. Specifically, we found that antibody responses to the $S(811-825), S(881-895)$ and $N(156-170)$ epitopes negatively or positively correlated with clinical severity or patient survival. Moreover, we found that the P681H and S235F mutations associated with the coronavirus variant B.1.1.7 altered the specificity of the corresponding epitopes.

CONCLUSIONS. Epitope-resolved antibody testing not only offers a high-resolution alternative to conventional immunoassays to delineate the complex humoral immunity to SARS-CoV-2 and differentiate between neutralizing and non-neutralizing antibodies, it may also be used as predictor of clinical outcome. The epitope peptides can be readily modified to detect antibodies against variants in both the peptide array and latex agglutination formats.

FUNDING. Ontario Research Fund (ORF)-COVID-19 Rapid Research Fund, the Toronto COVID-19 Action Fund, Western University, the Lawson Health Research Institute, the London Health Sciences Foundation, and the AMOSO Innovation Fund. 
medRxiv preprint doi: https://doi.org/10.1101/2021.03.16.21253716; this version posted March 20, 2021. The copyright holder for this preprint (which was not certified by peer review) is the author/funder, who has granted medRxiv a license to display the preprint in perpetuity.

All rights reserved. No reuse allowed without permission.

\section{INTRODUCTION}

The severe acute respiratory syndrome coronavirus-2 (SARS-CoV-2) has infected more than 100 million people worldwide since it was first identified in humans in 2019. The ensuing COVID-19 pandemic has put diagnostic testing at the forefront in the battle to stop the spread of the virus. Nucleic acid testing (NAT), which detects the virus RNA by reverse transcription polymerase chain reaction (RT-PCR), is the current gold standard for diagnosing acute infections(1). NAT has played a critical role in containing the pandemic by allowing expedient identification of infected individuals for treatment, isolation and contact-tracing. However, NAT alone cannot reveal the true prevalence of the SARS-CoV-2 infection because $20 \%-80 \%$ of all infections are likely asymptomatic(2-4). Therefore, a significant proportion of the population would be missed by NAT-based screening because the virus is typically cleared by the immune system in 3-4 weeks after infection or symptom onset. To complement NAT, serological assays for virus-specific antibodies have been developed(5-7). In contrast to NAT that can only detect acute infections, serology tests can identify past infections as antibodies may persist in the blood long after the virus has been cleared. The wide window of time within which antibodies may be detected, ranging from 1-2 weeks of infection when seroconversion occurs to several months after the infection is resolved, offers a unique advantage for antibody testing over NAT. Because of the high incidence of asymptomatic cases, antibody testing, when carried out in large scales, can provide valuable and accurate information about the spread of the infection at the population level and the true infection fatality rate $(8,9)$. Importantly, with the advent of several effective vaccines against the virus and the rapid rollout of the vaccination program around the world, priorities are being shifted from containment to monitoring the immediate and longitudinal effects of the vaccines on the immune system. This paradigm shift will undoubtedly increase the demand for antibody testing.

Numerous serological assays for SARS-CoV-2 antibodies have been developed to date, including enzyme-linked immunosorbent assays (ELISA), chemiluminescent immunoassays (CLIA) and lateral flow assays (LFAs) $(1,8)$. The sensitivity and specificity of different ELISA kits may vary(10), but they are generally considered sufficient for large-scale SARS-CoV-2 antibody testing. Nevertheless, the need for specialized equipment and trained personnel to perform the test and the long turn-around time makes it a challenge to use ELISA in point-of-care (POC) settings. In contrast, LFAs, which can be carried out in under 30 minutes with no equipment required, can potentially be used for POC testing. However, 
medRxiv preprint doi: https://doi.org/10.1101/2021.03.16.21253716; this version posted March 20, 2021. The copyright holder for this preprint (which was not certified by peer review) is the author/funder, who has granted medRxiv a license to display the preprint in perpetuity.

All rights reserved. No reuse allowed without permission.

LFA-based tests have been shown less sensitive and specific than ELISA $(6,9,11,12)$. Besides concerns over sensitivity, specificity and POC potential, both ELISA- and LFA-based antibody testing have the following limitations. First, current tests rely on the interaction of the Spike (S) or Nucleocapsid (N) protein or a fragment/domain of either protein to capture the corresponding antibody. These assays, which provide a single measure of antibody reactivity, are not ideal for gauging the diverse antibody responses observed in the clinic. Second, protein antigen-based immunoassays such as ELISA and LFA generate a composite signal across many epitopes, including both conformational and linear epitopes, and thereby lacking the necessary specificity or resolution to differentiate between neutralizing and nonneutralizing antibodies or predict clinical outcome. Indeed, patients who are older or with severe symptoms have been shown to produce more antibodies than those who are younger or with milder symptoms $(13,14)$, suggesting that robust antibody responses measured by conventional means do not correlate with effective humoral immunity. Third, current serological assays are ill-suited to assess the immunological effect of coronavirus variants as numerous recombinant proteins would have to be produced. Several mutated strains have emerged recently that are believed to be more contagious than the original SARS-CoV-2 strain $(15,16)$. These and other variants identified to date harbor numerous missense or deletion mutations in the $\mathrm{S}$ or $\mathrm{N}$ protein encoding gene that may alter their antigenic characteristics. To effectively curb the spread of these highly contagious variants, it is of paramount importance that we develop an antibody test that can readily incorporate the emerging mutations to determine the effect of these mutations and the corresponding coronavirus variants on the immune system. Fourth, current immunoassays are generally focused on testing a specific antibody isotype. Given the distinct dynamics of IgM, IgA and IgG in response to the SARS-CoV-2 infection(17, 18), it is necessary to develop a multiplex immunoassay to gauge humoral immunity. Lastly, with the vaccine rollout across the globe, a rapid and accurate POC test is urgently needed to gauge the effectiveness of a vaccine and monitor the duration of antibody responses in large populations to provide valuable information on herd immunity.

We addressed these unmet needs in SARS-CoV-2 antibody testing using protein and peptide arrays, which led to the identification of linear epitopes that mediate the complex antibody responses observed in a group of 89 COVID-19 patients. This, in turn, allowed us to develop a "master epitope array" containing the major epitopes and use it to gauge antibody responses with greater resolution than is attainable by protein antigen-based immunoassays. We found that the antibody profiles determined by linear epitopes, but not by the $\mathrm{S}$ or $\mathrm{N}$ protein, could distinguish patients with moderate or severe diseases 
medRxiv preprint doi: https://doi.org/10.1101/2021.03.16.21253716; this version posted March 20, 2021. The copyright holder for this preprint (which was not certified by peer review) is the author/funder, who has granted medRxiv a license to display the preprint in perpetuity.

All rights reserved. No reuse allowed without permission.

or with favorable or fatal outcomes. Using a peptide array recapitulating the mutations found in SARSCoV-2 variants, we showed that certain mutations abolished binding of the corresponding epitopes to antibodies against the original strain. Furthermore, the identified epitopes enabled us to develop an epitope-dependent agglutination assay for SARS-CoV-2 antibodies. This rapid agglutination assay is not only highly accurate, but it may also be readily modified to incorporate specific epitopes, including variant epitopes, to profile the complex antibody responses in individuals.

\section{RESULTS}

\section{Antibody responses to the $\mathrm{S}$ or $\mathrm{N}$ protein are not correlated with clinical outcome}

To develop a comprehensive antibody test, we first employed a protein array to identify the SARS-CoV2 antigens mediating antibody responses. Previous studies have implicated the $\mathrm{S}, \mathrm{N}$ and the nonstructural proteins encoded by the ORFlab gene as the major antigens eliciting humoral immune response in the host $(19,20)$. We therefore expressed these proteins, including various different fragments or domains of $\mathrm{S}$ and $\mathrm{N}$, in bacterial or mammalian cells. Upon purification, the recombinant virus proteins were printed on nitrocellulose coated glass slides. The resulting proteome array, featuring 16 SARS-CoV-2 proteins and human IgG as the positive control (Fig. 1A, Table S1), was probed with plasma samples from patients that tested positive or negative for SARS-CoV-2 by RT-PCR (10). The bound IgG was detected using goat anti-human IgG conjugated to the horseradish peroxidase (HRP) (Fig. S1).

We screened the proteome array and subsequent peptide arrays (vide infra) with 146 plasma samples from 89 hospitalized patients, including serial samples collected for some patients on different days after diagnosis. The patients were divided into two groups with severe (i.e., requiring intensive care) or moderate (i.e., no intensive care required) disease. The same patient cohort was also classified according to clinical outcome into the "alive" or "fatal" group, with the former comprising those who survived the infection and the latter who ultimately succumbed to the disease. As shown in Fig. 1B, both the moderate and severe groups showed IgG responses to the Spike (including the ectodomain S-Ecto and the receptor binding domain S-RBD) and the nucleocapsid protein (including the RNA-binding domain N-RBD and the dimerization domain N-Dimer). In contrast, no significant IgG binding signal was detected for the NSP proteins (Fig. 1A-C; Fig. S2). These results are consistent with previous findings by others that 
medRxiv preprint doi: https://doi.org/10.1101/2021.03.16.21253716; this version posted March 20, 2021. The copyright holder for this preprint (which was not certified by peer review) is the author/funder, who has granted medRxiv a license to display the preprint in perpetuity.

All rights reserved. No reuse allowed without permission.

Spike and nucleocapsid are the main antigenic proteins in SARS-CoV-2(19-23). For the ICU patients with serial plasma samples, we found that the $\mathrm{S} / \mathrm{N}$-specific IgG signals increased from day 1 (of ICU admission) to days 7 and 10 for both the alive and the fatal groups (Fig. 1C). This indicates that humoral immune responses became more robust with time in these patients regardless of outcome.

Overall, we found that all seroconverted patients showed IgG responses to either the $\mathrm{S}$ or $\mathrm{N}$ protein or both. A greater percentage of the severe patient group had antibodies specific for S-RBD or S-Ecto than those with moderate conditions. In contrast, the difference in N-specific IgG signal was small between the two groups (Fig. 1D). Compared to the group that survived, the fatality group more frequently exhibited S- or N-specific antibodies (Fig. 1E), suggesting once again that a robust antibody response does not necessarily translate to a favorable outcome. In corroboration of this assertion, we found no correlation between the strength of S- or N-specific IgG signal and disease severity or outcome (Fig. 1FG). Taken together, the proteome array screen data demonstrate that the S- or N-antibody response is not a sensitive barometer of COVID-19 clinical severity or outcome.

\section{Systematic identification of linear epitopes by peptide microarrays}

Antibody specificity is determined by epitopes on the protein antigen, including both linear and conformational epitopes(23). Because linear epitopes are small peptides (5-20 residues), they may be identified by screening peptides generated by chemical or genetic means(19, 20, 22). To identify the linear epitopes mediating the SARS-CoV-2 antibody responses, we synthesized peptides representing the candidate epitopes reported in the literature (up to October 2020)(24, 25) and printed the peptides on a nitrocellulose coated glass slide. The resulting peptide array, containing 89 reported epitopes for the $\mathrm{S}$, $\mathrm{N}$, and M (membrane) proteins (Fig. 2A), was probed with patient plasma samples. Intriguingly, we were only able to detect $<50 \%$ of the reported epitopes in our peptide array screens (Fig. S3; Table S2). While the large discrepancy might be attributed, in part, to the different techniques used for assaying the epitope-antibody interaction, it prompted us to redefine the epitopes using the peptide array approach. To this end, we created a peptide microarray to represent the complete $\mathrm{S}$ and $\mathrm{N}$ protein sequences. The resulting “peptide-walking” array contained 333 tiled 15-mer peptides with 5-residue overlap between two consecutive peptides (Fig. 2A). 
medRxiv preprint doi: https://doi.org/10.1101/2021.03.16.21253716; this version posted March 20, 2021. The copyright holder for this preprint (which was not certified by peer review) is the author/funder, who has granted medRxiv a license to display the preprint in perpetuity.

All rights reserved. No reuse allowed without permission.

We screened the peptide microarray with 15 patient plasma samples, including 14 COVID-19 patient samples and 1 SARS-CoV-2 ${ }^{-}$control (Fig. S4). This led to the identification of 54 potential epitopes from the $\mathrm{S}$ and $\mathrm{N}$ protein (Table 1). While the majority of the candidate epitopes are likely minor ones based on the weak IgG-binding signals, some produced strong signals (Fig. S4, Table 1), suggesting that they may be major epitopes mediating the $\mathrm{S}$ or $\mathrm{N}$ antibody response. To profile antibody response in a systematic manner, we generated a "master epitope array" containing 16 major epitopes selected based on the corresponding IgG signal strength from the peptide-walking array screen. The master array also contained $\mathrm{S}$ and $\mathrm{N}$ protein antigens as controls (Fig. 2A; Table 1; Fig. S5).

\section{Epitope-resolved antibody profiling distinguishes COVID-19 cases based on severity or outcome}

Using the master array, we screened plasma samples from the 89 COVID-19 patients and 9 SARS-CoV$2^{-}$control subjects (Fig. 2 B-C; Fig. S6). We found that the plasma from ICU (severe) group recognized significantly more epitopes than the non-ICU (moderate) group (Fig. 3A). Certain epitopes, including S$811, \mathrm{~S}-881, \mathrm{~N}-6$ and N-361, were detected more frequently in the severe cases than in the moderate cases whereas other epitopes, including S-451 and N-156, showed the opposite trend (Fig. 3B). By comparison, the number of IgG-binding epitopes were not significantly different between patients who survived or succumbed to the disease even though the latter group, in general, tended to have antibodies reactive to more epitopes (Fig. 3C). Nevertheless, antibodies to the S-811, S-881 and N-361 epitopes were found enriched in the fatality group whereas antibodies to N-6, S-451, S-551 and S-671 were detected only in the survivor group (Fig. 2D).

In addition to epitope frequency, the intensity of IgG-binding signals to certain epitopes were found correlated positively or negatively with clinical severity or outcome. In general, we found that moderate cases tended to have stronger antibody responses to N-156 whereas more robust antibody responses against the S-811 and S-881 epitopes were observed for the severe cases (Fig. 3E). Indeed, COV+14 was the only moderate case among the tested cases with strong S-811 and S-881 antibodies which, intriguingly also featured a robust S-671 antibody response. Overall, the patients with fatal disease were characterized with significantly stronger S-811- or S-881-specific antibodies than those who survived the infection (Fig. 3F). This indicates that antibody responses to these epitopes are detrimental to COVID-19 disease progression. The S-811 and S-881 epitopes are located in a region of the spike protein buried in the prefusion conformation, which, however, becomes disordered and exposed following virus 
medRxiv preprint doi: https://doi.org/10.1101/2021.03.16.21253716; this version posted March 20, 2021. The copyright holder for this preprint (which was not certified by peer review) is the author/funder, who has granted medRxiv a license to display the preprint in perpetuity.

All rights reserved. No reuse allowed without permission.

fusion with the host cell membrane (Fig. 3G). Therefore, it is likely that the production of antibodies specific for the S-811- or S-881 epitopes coincides with the state of the coronavirus undergoing active host cell infection. In contrast, the S-671 epitope, mutated in the UK variant B.1.1.7, is located at the S1/S2 cleavage site critical for virus infection(26) (Fig. 3G).

\section{Mutations found in SARS-CoV-2 variants alter epitope specificity}

Numerous mutations have been identified in SARS-CoV-2 variants, the vast majority of which occur on the spike protein which plays a critical role in host cell infection and immune response. The recent emergence of several variants in the United Kingdom (UK), South African (SA) and Brazil, which have been shown to be more contagious than the original strain, has raised concerns over the efficacy of mRNA vaccines that are used to produce the wild-type Spike protein in the recipient. We investigated this possibility using peptides representing 28 major $\mathrm{S}$ or $\mathrm{N}$ missense mutations or deletions identified to date, including those found in the UK variant B.1.1.7., the SA variant 501.V2 and mutations shown to alter antibody binding in a previous study(27) (Table 2). A peptide array containing the mutated epitopes and the matching counterparts in the original SARS-CoV-2 strain was created and screened with patient plasma (Fig. 4A). Because only a few mutations reside within the identified epitopes (Table 2), the mutated epitope screen was focused on plasma samples that showed robust antibody responses to the corresponding wild-type epitopes on the master array (Fig. 2B). Intriguingly, we found that the mutations either reduced or completely abolished IgG binding for the corresponding epitopes. For example, substitution of the S235 residue with a Phe in the N-221 epitope, a mutation found in the B.1.1.7 variant, eliminated IgG binding. Similarly, S-671 was identified as a major epitope in the $\mathrm{COV}+14$ patient by the master array. The introduction of the $\mathrm{P} 681 \mathrm{H}$ mutation, found in the Spike protein of the UK variant, into the S-671 peptide, completely abolished antibody binding. To confirm this finding, we synthesized another version of the S-671 epitope in which the P681 residue and the P681H mutation were placed in the center of the corresponding peptides and printed both versions of the original and mutant peptides in incremental concentrations in an array. This peptide gradient array was then probed with the $\mathrm{COV}+14$ plasma collected on days 1, 2 and 3 of hospitalization. While the original epitopes exhibited increased IgG-binding with time, the P681H-containing epitope did not show detectable antibody binding signal for the same samples. These data indicate that the P681H mutation altered the specificity of the corresponding epitope (S-671) and rendered it unrecognizable by antibodies 
medRxiv preprint doi: https://doi.org/10.1101/2021.03.16.21253716; this version posted March 20, 2021. The copyright holder for this preprint (which was not certified by peer review) is the author/funder, who has granted medRxiv a license to display the preprint in perpetuity.

All rights reserved. No reuse allowed without permission.

against the original coronavirus (as the plasma sample was collected prior to the emergence of the B.1.1.7 variant).

\section{A rapid agglutination assay to gauge epitope-specific antibody response}

While the epitope peptide array may be used to determine antibody specificity in a systematic manner, it is not suitable for POC testing. Nevertheless, the identification of specific epitopes that are either common to the COVID-19 patients examined or unique to groups with distinct clinical severity or outcome prompted us to develop a rapid test based on these epitopes to complement the peptide array assay. Inspired by the principle of antibody-dependent red blood cell agglutination(28), we developed an epitope-dependent agglutination assay to detect epitope-specific antibody response. Specifically, latex beads were coated with streptavidin and conjugated to one or more biotinylated epitope peptides. Antibodies specific to the epitopes were found to induce the agglutination of the corresponding latex beads in minutes (Fig. 5A), with the area of agglutination serving as a proxy of antibody titer. In principle, the latex bead agglutination assay detects the total antibodies (including $\operatorname{IgG}, \operatorname{IgM}$ and $\operatorname{IgA}$ ) rather than a specific isotype. To develop an epitope test to replace the $\mathrm{S}$ and $\mathrm{N}$ antigens, we coated the latex beads with the most prominent $\mathrm{S}$ or $\mathrm{N}$ epitopes. Specifically, latex beads were coated with a mixture of the S-811 and S-1146 (2S) peptides to represent the S antigen or the N-156 and N-361 (2N) peptides to represent the $\mathrm{N}$ antigen. When evaluated using plasma samples from individuals who tested positive (COVID+) or negative (COVID-) for the SARS-CoV-2 virus or samples from healthy donors collected in 2018 (PreCOVID), the 2S- and 2N-based agglutination assays showed 100\% specificity and 99\%100\% sensitivity (Fig. 5B).

To determine if the epitope-dependent agglutination assay could differentiate the different patient groups as effectively as the master epitope array, we coated the latex beads with the S epitope S-811, S-881 or S-551 or the N epitope N-156 or N-361 and performed agglutination assay on COVID-19 patient plasma or control (COVID-) specimen. While no agglutination was observed for the COVID- plasma, the COVID+ plasma promoted the agglutination of the latex beads in an epitope-dependent manner. We found that the group with severe disease had significantly greater S-811- and N-361-specific antibody responses than the group with moderate conditions. The reverse was found true for the N-156 epitope. Similarly, significant differences in antibodies specific for the S-811, S-881, S-551 and N-156 epitopes were observed between the alive and fatality groups. Notably, a high level of S-811-dependent 
medRxiv preprint doi: https://doi.org/10.1101/2021.03.16.21253716; this version posted March 20, 2021. The copyright holder for this preprint (which was not certified by peer review) is the author/funder, who has granted medRxiv a license to display the preprint in perpetuity.

All rights reserved. No reuse allowed without permission.

agglutination was strongly and significantly correlated with patient death whereas even a moderate level of S-551-specific antibody response was correlated significantly with favorable outcome. These data not only reinforced our findings from the master epitope peptide array screen but extended these findings by identifying a group of key epitopes, including S-811, S-881, S-551 and N156, that collectively may help predict the clinical severity and outcome of the COVID-19 disease.

\section{Correlation of epitope-specific antibody response with neutralizing efficiency and disease outcome}

Because neutralizing antibodies play a pivotal role in the humoral immune response to the SARS-CoV2 infection, we used a surrogate neutralization assay to measure efficacy of patient plasma in blocking S-RBD binding to its host receptor, angiotensin converting enzyme 2 (ACE2) in vitro(29). We found that the neutralization efficiency of the plasma in the severe patient group was significantly higher than the group with moderate disease. Intriguingly, the plasma from the fatality group were significantly less efficient in neutralizing S-RBD binding to ACE2 compared to patients who recovered from the infection (Fig. 6A). This suggests that the ability to inhibit the S-RBD-ACE2 interaction, the critical first step in SARS-CoV-2 infection of host cells, dictates disease outcome. Because the identified S epitopes reside outside of the RBD domain of the spike protein, due perhaps to the possibility that the antibody-RBD recognition involves primarily conformational epitopes(23), we replaced the $\mathrm{S}$ epitopes with recombinant $\mathrm{RBD}$ and repeated the agglutination assay using the same plasma samples. We found that the S-RBD-dependent antibody response measured by latex agglutination significantly correlated with favorable outcome (Fig. 6B).

Can the epitope-specific antibody response be used to predict neutralization efficiency? We investigated this possibility by correlating the epitope-specific agglutination data with the neutralization data for the same set of patient samples. We found that the S-811-specific antibody response correlated with the neutralization efficiency negatively $(\mathrm{r}=-0.72, \mathrm{p}<0.05)$ in the alive patient group, but positively in the severe $(\mathrm{r}=0.68)$ or fatality $(\mathrm{r}=0.64)$ patient group. In contrast, the $\mathrm{S}-\mathrm{RBD}$-dependent agglutination efficiency was positively correlated with neutralization efficiency $(\mathrm{r}=0.68)$ in the alive group(30) (Fig. 6C). Collectively, these data suggests that a strong S-RBD antibody response together with a weak S811-specific response are indicative of favorable clinical outcome.

\section{DISCUSSION}


The relationship between COVID-19 clinical severity and the humoral immune response is a complex one. It remains poorly understood to date why patients with severe symptoms are characterized with a stronger antibody response, including neutralization antibodies, to SARS-CoV-2 than those who have moderate or mild symptoms $(30,31)$. This dichotomy suggests that not all antibodies are beneficial. Indeed, while antibodies may mediate the clearance of the virus and virus-infected cells through antibody-dependent cellular cytotoxicity (ADCC) and phagocytosis (ADCP), they have also been proposed to play a pathogenic role via antibody-dependent enhancement (ADE)(32). The challenge is how to identify and differentiate between "good" and "bad" antibodies. Our epitope-based antibody analysis showed that the antibody responses from different patients are highly varied, and that there is generally no apparent association between the severity of disease presentation and antibody response measured using a protein antigen, including the Spike $(\mathrm{N})$ or Nucleocapsid $(\mathrm{N})$. Therefore, antibody profiling with greater resolution than a simplified $\mathrm{S}$ or $\mathrm{N}$ antibody classification is needed. Our work, which combines both systematic antibody screen using peptide/protein arrays and rapid antibody assays based on latex agglutination, showed that epitope-resolved antibody testing is far more sensitive than $\mathrm{S} / \mathrm{N}$-based serology tests in discerning antibody specificity and identifying the correlates between humoral immunity and COVID-19 disease severity or patient survival.

By identifying and validating the major $\mathrm{S}$ and $\mathrm{N}$ epitopes to enable epitope-specific antibody testing, our study not only greatly extended previous work that show linear epitopes play a critical role in mediating antibody responses to SARS-CoV-2 $(19,20,22,24,33)$, but more importantly, it demonstrated that the complex antibody responses in individual patients may be deconvoluted by epitope-resolved antibody profiling. Systematic and unbiased antibody profiling using a master array comprising the most prominent epitopes led to several intriguing findings. First, patients with severe disease or poor outcome tend to have antibodies against a large number of epitopes. We showed that these same patients had low levels of neutralizing antibodies. It is therefore likely that the increased production of non-neutralizing antibodies contributed to disease development. Second, all epitopes are not equal, and even the epitopes from the same protein antigen ( $\mathrm{S}$ or N) may play distinct roles in dictating disease severity and outcome. We have shown that not only S-811 and S-881 are two of the most prevalent epitopes, but also a high level of antibodies specific for these epitopes are strongly indicative of severe or fatal disease. That the S-811 antibody response is negatively correlated with neutralization efficiency in patients who survived the infection suggests that the S-811-driven antibody response may be indicative of more aggressive or 
medRxiv preprint doi: https://doi.org/10.1101/2021.03.16.21253716; this version posted March 20, 2021. The copyright holder for this preprint (which was not certified by peer review) is the author/funder, who has granted medRxiv a license to display the preprint in perpetuity.

All rights reserved. No reuse allowed without permission.

effective virus infection of the host cells. Alternatively, antibody response targeting these epitopes may be a surrogate marker for a more robust and potentially excessive immune response causing greater tissue injury. Third, we have shown that mutations found in SARS-CoV-2 variants may directly affect antibody response by altering epitope specificity. This finding demonstrated the flexibility of the epitope peptide array approach to quickly incorporate emerging mutations, thereby providing valuable information of the mutations and the corresponding variants on the immune system.

While it has been shown that mutations result in more fit, and likely more contagious viruses(15, 16, 34), the serological consequences of the mutations found in SARS-CoV-2 variants are unclear(34). Recent studies have shown reduced binding to therapeutic antibodies or Spike-specific antibodies for the circulating variants B.1.1.7, 501Y.V2 and P.1 in vitro $(35,36)$, suggesting that mutations in these variants directly affect antibody response. In agreement with this assertion, we found that certain mutations, including the $\mathrm{P} 681 \mathrm{H}$ in the Spike and S245F in the Nucleocapsid proteins, rendered the corresponding epitopes completely incapable of binding antibodies specific for the original virus. This observation raises concerns over the effectiveness of vaccines in protecting against the coronavirus variants that are currently circulating or variants, including variant recombination, that may emerge in the future (14). While it remains to be determined whether this mutation could mediate immune escape of the variant in some patients, our finding may have far-reaching implications as it may render the wildtype Spike mRNA-based vaccine less effective to those who employ S-671 (which encompass the mutated residue) as a major epitope. However, we note that the $\mathrm{P} 681 \mathrm{H}$ and $\mathrm{S} 235 \mathrm{~F}$ mutations only affected a few individuals in the cohort of patients examined herein while the majority of patients displayed no apparent antibody responses against the corresponding epitopes. This may explain why recent studies have shown the Pfizer and Moderna mRNA vaccines are effective in protecting from infection by the variant (37-39). It would be important to investigate in the future, by large-scale epitopespecific antibody profiling, the percentage of the population who employ S-671 as a major epitope. By the same token, prevalence of the N-221 epitope (which contains the S235 residue found mutated in the UK strain) would provide valuable information on the protection of vaccines based on inactivated intact viruses. In the same vein, hundreds of mutations may be examined simultaneously in a peptide array to assess their effect on antibody response, and the epitope array may be readily modified to incorporate emerging mutations. The impact of the mutations on humoral immune response may also involve conformational epitopes which are not recapitulated by the linear epitopes. However, both the master array and the agglutination-based antibody test may be quickly modified to include emerging mutations. 
medRxiv preprint doi: https://doi.org/10.1101/2021.03.16.21253716; this version posted March 20, 2021. The copyright holder for this preprint

Future studies using a combination of epitope and protein antigen-based assays tailored to emerging variants would provide valuable information on the population penetrance of a given variant and the impact the associated missense or deletion mutations on antibody-mediated immunity.

While the epitope array may be used to profile antibody response in a systematic manner, the epitopedependent latex agglutination assay provides a rapid, simple, cost-effective, and accurate serological test that may be suitable for POC antibody testing. The agglutination assay may be carried out with individual epitopes to map the specificity of antibodies or with a mixture of epitopes to test multiple antigens simultaneously. The ease with which to incorporate mutated epitopes or $\mathrm{S} / \mathrm{N}$ protein antigen in the agglutination assay makes it a nimble yet powerful tool to determine the impact of mutations associated with the coronavirus variants on humoral immunity. Although the mRNA-based vaccines have shown superb efficacy, not all vaccine recipients would be protected. It also remains to be determined how long the immunity will last and against which variant. Monitoring vaccinated or recovered individuals over months to years by antibody testing would provide valuable information on the duration of immune responses against SARS-CoV-2, including variants (7). In this regard, the epitope-resolved antibody test may be used to delineate the specific antibodies produced by different individuals, determine persistence of antibody in the circulation over time, assess the efficiency of vaccines, and decipher the effect of emerging variants on the immune system. The agglutination assay, which measures the total antibody response irrespective of the Ig isotypes, provides a unique advantage over serological assays that measure a given isotype as different Ig isotypes have distinct dynamics and evolutionary trajectory over time(18). Longitudinal studies by the epitope-resolved agglutination assay would provide valuable information on the evolution of antibody immunity from vaccination or previous infection.

With the rapid spread of the highly contagious coronavirus variants, the number of patients that need treatment will likely remain high for quite some time. In the absence of an effective treatment, convalescent plasma and antibody therapy remain a good option. However, clinical trial results are mixed for either approach, highlighting the need for more specific screening strategies to identify the most effective convalescent plasma or therapeutic antibody. It would be interesting to find out if the epitoperesolved antibody profiling strategy developed herein may be used to identify convalescent plasma donors with a high level of neutralization antibody and a low level of non-neutralizing and potentially harmful antibodies. Similarly, the epitope specificity mapping could enable the selection of the most effective therapeutic antibody with the least side-effects. 
medRxiv preprint doi: https://doi.org/10.1101/2021.03.16.21253716; this version posted March 20, 2021. The copyright holder for this preprint (which was not certified by peer review) is the author/funder, who has granted medRxiv a license to display the preprint in perpetuity.

\section{METHODS}

\section{Blood sample collection}

Blood samples were collected following a protocol (study number: 116284) approved by the Research Ethics Board (REB) of Western University. The residual plasma samples were de-identified prior to transfer from the Core Laboratory (London Health Sciences Center, London, Canada) to a biosafety Level 3 (CL3) lab (ImPaKT, Western University) following Transportation of Dangerous Goods (TDG) guidelines. All plasma samples were heat-inactivated at $56^{\circ} \mathrm{C}$ for 30 minutes at the ImPaKT CL3 facility as per Western University biosafety regulation. Heat inactivated plasma samples were then transferred to the testing laboratory.

\section{Protein Microarray}

Proteins. The Spike-ectodomain(40), Nucleocapsid-dimerization domain, Nucleocapsid-RNA binding domain, NSP3-unique, NSP3-ADRP, NSP3-NAB, NSP3-PLPro, NSP4-CTD, NSP5, NSP7, NSP8, NSP9, NSP10, NSP16(41) were supplied by the Toronto Open Access Covid-19 Protein Manufacturing Center (comprising BioZone and the Structural Genomics Consortium (SGC)) under an Open Science Trust Agreement http://www.thesgc.org/click-trust. The Center received funding from the Toronto COVID-19 Action Fund. See Supplementary Table S1 for a complete list of proteins

Protein Array Printing. SARS-CoV-2 proteins were diluted to $0.5-10 \mu \mathrm{M}$ in PBS with 5\% glycerol (IgG control at $200 \mathrm{nM}$ ) and aliquots transferred to a 384-well microplate (ArrayIt). 24 copies of the microarray were printed on each nitrocellulose coated glass slide (ArrayIt) using a VersArray Chipwriter Pro (Bio-Rad) equipped with a Stealth $15 \mathrm{XB}$ microarray quill pin (ArrayIt). Spot to spot distance was $850 \mu \mathrm{m}$ with two reprints of the same spot and all spots printed in duplicate in the y dimension. A dwell time of $0.1 \mathrm{sec}$ was used for each spot with an approach speed of $12.5 \mathrm{~mm} / \mathrm{sec}$. Samples were printed at room temperature and subsequently stored at $4^{\circ} \mathrm{C}$ until time of probing.

\section{Peptide Microarray}

Peptide synthesis. Peptides were synthesized on Tentagel resin on an Intavis MultiPep RSi peptide synthesizer using N-(9-fluorenyl) methoxycarbonyl (Fmoc) chemistry. All peptides were synthesized with biotin at the $\mathrm{N}$ terminus followed by an aminohexanoic acid and Gly-Gly spacer. A walking array of peptides with 15 amino acid length and 5 amino acid overlap spanning the full sequence of SARS- 
medRxiv preprint doi: https://doi.org/10.1101/2021.03.16.21253716; this version posted March 20, 2021. The copyright holder for this preprint (which was not certified by peer review) is the author/funder, who has granted medRxiv a license to display the preprint in perpetuity.

All rights reserved. No reuse allowed without permission.

CoV-2 Spike and Nucleocapsid proteins were synthesized for array printing. Peptides reported in a previous publication(24) as well as epitopes predicted using bioinformatics(25) were synthesized and printed to create the literature-reported peptide array. Peptides encompassing mutation sites reported in SARS-CoV-2 variants were synthesized as described above for the variant peptide array (Table 2).

Peptide Array Printing. Peptides were printed as neutravidin complexes on nitrocellulose coated slides (ArrayIt) by mixing $10 \mu \mathrm{M}$ neutravidin with an excess (by four-fold) of peptide that was diluted in phosphate buffered saline and aliquots transferred to a 384-well microplate (ArrayIt) along with IgG printing control, Spike RBD, full length Nucleocapsid, N-RBD and N-Dimerization proteins. 2 copies of the walking microarray, 3 copies of the literature-reported microarray, or 8 copies of the variant array were printed on each nitrocellulose coated glass slide using a VersArray Chipwriter Pro (Bio-Rad) equipped with a Stealth $15 \mathrm{XB}$ microarray quill pin (ArrayIt). Spot to spot distance was $750 \mu \mathrm{m}$ with two reprints of the same spot and all spots printed in duplicate in the y dimension. A dwell time of $0.1 \mathrm{sec}$ was used for each spot with an approach speed of $12.5 \mathrm{~mm} / \mathrm{sec}$. Samples were printed at room temperature and subsequently stored at $4^{\circ} \mathrm{C}$ until time of probing

\section{Protein and Peptide Array Probing}

Microarray slides were briefly rinsed twice with TBST (Tris buffered saline containing Tween 20: 0.1M Tris- $\mathrm{HCl}, \mathrm{pH} 7.4,150 \mathrm{mM} \mathrm{NaCl}$, and $0.1 \%$ Tween 20) to wet the surface and then incubated for 2 hours with ChonBlock ELISA blocking and antibody dilution buffer (Chondrex Inc). Slides were briefly rinsed with TBST then inserted into an ArraySlide 24-chamber hybridization cassette (The Gel Company) for the proteome array or ProPlate Multi-Well Chamber (Grace Bio-Labs) for the peptide arrays and incubated with plasma from SARS CoV-2 NAT confirmed positive and negative patients (1:250 dilution in ChonBlock). Slides were then rinsed quickly three times followed by three $5 \mathrm{~min}$ washes with TBST before probing with goat anti-human IgG HRP antibody at 1:10,000 (Millipore Sigma) in ChonBlock for $1 \mathrm{~h}$. The wash step was repeated as above, then the HRP signal was visualized on a ChemiDoc XRS+ Imager (Bio-Rad) using Clarity ECL Substrate (Bio-Rad). Slides were incubated with ECL solution for 30 seconds then 15 images were taken incrementally from 1-60 seconds. All incubation steps were performed at room temperature using a rocker for agitation of sample.

\section{Array Quantification}


medRxiv preprint doi: https://doi.org/10.1101/2021.03.16.21253716; this version posted March 20, 2021. The copyright holder for this preprint (which was not certified by peer review) is the author/funder, who has granted medRxiv a license to display the preprint in perpetuity.

All rights reserved. No reuse allowed without permission.

Peptide walking arrays, literature-reported epitope peptide arrays and the master epitope arrays were quantified using ImageJ software(42). Images were first inverted and converted to 8-bit. Background was subtracted using a rolling ball radius of 25.0 pixels. Intensities were normalized to IgG control and ranked by normalized signal intensity. Peptides with strongest intensity or most frequently observed were selected for creation of the master array. For the master array, samples with no detectable antibody response or samples with signals within 2 standard deviations of the mean background intensity were omitted from statistical analysis.

\section{Preparation of SARS-CoV-2 peptide antigen conjugated latex particles and peptide antigen-based agglutination assay}

Blue dyed carboxylate-modified, streptavidin-polystyrene latex beads, $0.25 \mu \mathrm{m}$ in diameter or blue dyed polystyrene latex beads, 0.8 mm in diameter, were purchased from Sigma Aldrich (L6155, L1398). Carboxylate-modified latex-streptavidin or neutravidin coated polystyrene beads were suspended at $2.5 \%(\mathrm{w} / \mathrm{v})$ using assay buffer, 0.025M MES-Tween 20 buffer (2-(N-Morpholino) ethanesulfonic acid, $0.05 \% \mathrm{pH}$ 6.0). Synthetic biotin-labeled SARS-CoV-2 peptides were suspended in the same assay buffer at the concentration $500 \mu \mathrm{g} / \mathrm{ml}$. The biotin-peptides were incubated with streptavidin-latex beads for 1 hour at room temperature. The epitope peptide-conjugated latex beads complex was washed twice with PBS buffer (135 mM NaCl, $2.6 \mathrm{mM} \mathrm{KCl,} 8 \mathrm{mM} \mathrm{Na} 2 \mathrm{HPO}$, and $1.5 \mathrm{mM} \mathrm{KH2PO4,} \mathrm{pH} \mathrm{7.4)} \mathrm{by} \mathrm{mixing}$ and centrifuging the latex suspension at 5,000g for $10 \mathrm{~min}$. The peptide antigen-bead conjugate was blocked for $30 \mathrm{~min}$ at room temperature in PBS containing 3\% bovine serum albumin (BSA). The conjugate was then resuspended at $2.5 \%(\mathrm{w} / \mathrm{v})$ in PBS containing $1 \% \mathrm{BSA}$ and stored at $4^{\circ} \mathrm{C}$ until use. For the agglutination assay, $5 \mu 1$ plasma was mixed with $25 \mu 1$ peptide-conjugated latex beads $(2.5 \%$, $\mathrm{w} / \mathrm{v}$ ) per assay as described in the full protein antigen agglutination assay.

\section{Agglutination assay for SARS-CoV-2 antibody testing and data interpretation}

For the agglutination assay, $5 \mu \mathrm{l}$ plasma was mixed with $25 \mu \mathrm{l}$ antigen-coated beads $(2.5 \%$, w/v) per assay. The agglutination was allowed to proceed for $2 \mathrm{~min}$ at room temperature before imaging with a camera. The relative degree of agglutination induced by the SARS-CoV-2 antibody was measured by the area of clump formation based on the corresponding image. The image analysis software Qupath (v0.1.2) was used (https://qupath.github.io/) and quantification was done by calculating the percentage of agglutination based on estimated agglutination/clumps area $\left(\mathrm{mm}^{2}\right)$ relative to the total latex reaction area. 
medRxiv preprint doi: https://doi.org/10.1101/2021.03.16.21253716; this version posted March 20, 2021. The copyright holder for this preprint (which was not certified by peer review) is the author/funder, who has granted medRxiv a license to display the preprint in perpetuity.

All rights reserved. No reuse allowed without permission.

\section{S-RBD-ACE2 binding ELISA surrogate neutralization assay}

Biotin-ACE2 $(1 \mu \mathrm{g} / \mathrm{m})$ was added to S-RBD-coated plate after blocking and incubated for 1hour at room temperature. The wells were washed 3 times with TBST (20 mM Tris, $150 \mathrm{mM} \mathrm{NaCl,} \mathrm{0.1 \%} \mathrm{Tween} \mathrm{20)}$ to remove unbound biotin-ACE2. Streptavidin-HRP (1000-fold dilution with Chonblock blocking buffer) was then added to each well and incubated for 1 hour at room temperature. The wells were washed 3 times with TBST and TMB substrate (3,3',5,5'-Tetramethylbenzidine, Thermo Scientific, N301) was added for reaction development and $0.18 \mathrm{M} \mathrm{H} 2 \mathrm{SO} 4$ was used to stop reaction. Absorbance at 450nm was measured to detect the S-RBD bound ACE2. To determine the neutralization efficacy of the patient plasma, the plasma was diluted 1:100 and incubated with S-RBD-coated wells (blocked) for 1hour at room temperature. The wells were washed three times with TBST. Biotin-ACE2 was then added to the wells and incubated for 1 hour at room temperature followed by washing, reaction development and detection as described above.

\section{Statistical analysis}

All statistical analyses were done using the GraphPad Prism9 software.

\section{AUTHOR CONTRIBUTIONS}

SSCL, ICY, CV, SE and XL conceived and designed the study. CV performed the protein and peptide array screens and data analysis. SE performed the agglutination and neutralization assay and data analysis. XL, SZ synthesized the peptides. SA, PS, AS, AH, FY, TS, EE, PL, PG, and TH contributed to subcloning, expression and purification of SARS-CoV-2 proteins and human ACE2. MK, MJK, LL, HA, BDH, VB, CMM, MS, DF contributed to patient recruitment, blood sample collection and NAT and ELISA testing. TK and BCY contributed to data analysis and interpretation. SSCL, CV and SE wrote the manuscript with input from ICY, BCY, SA, MK, and DF.

\section{ACKNOWLEDGEMENT}

We thank the Center for Structural Genomics of Infectious Diseases (CDGID) for the N-RBD expression plasmid, Dr. Jason McLellan for human ACE2 and Spike ectodomain expression plasmids, Dr. Shane Harding for the spike-receptor binding domain expression construct, and Yanjun Li for technical assistance. This work was supported by grants from the Ontario Research Fund-COVID-19 Rapid 
medRxiv preprint doi: https://doi.org/10.1101/2021.03.16.21253716; this version posted March 20, 2021. The copyright holder for this preprint (which was not certified by peer review) is the author/funder, who has granted medRxiv a license to display the preprint in perpetuity.

All rights reserved. No reuse allowed without permission.

Research Fund, the Toronto COVID-19 Action Fund, Western University (Research), the Departments of Medicine and Pediatrics at Western University, the Lawson Health Research Institute (https://www.lawsonresearch.ca/), the London Health Sciences Foundation (https://lhsf.ca/), and the AMOSO Innovation Fund. SE was supported by a Post-Doctoral Fellowship from the National Science and Engineering Council of Canada. SSCL holds a Canada Research Chair in Molecular and Epigenetic Basis of Cancer.

\section{REFERENCES}

1. Ravi N, Cortade DL, Ng E, and Wang SX. Diagnostics for SARS-CoV-2 detection: A comprehensive review of the FDA-EUA COVID-19 testing landscape. Biosens Bioelectron. 2020;165:112454.

2. Long QX, Tang XJ, Shi QL, Li Q, Deng HJ, Yuan J, et al. Clinical and immunological assessment of asymptomatic SARS-CoV-2 infections. Nat Med. 2020;26(8):1200-4.

3. Sakurai A, Sasaki T, Kato S, Hayashi M, Tsuzuki SI, Ishihara T, et al. Natural History of Asymptomatic SARS-CoV-2 Infection. N Engl J Med. 2020;383(9):885-6.

4. Keeley AJ, Evans CM, and de Silva TI. Asymptomatic SARS-CoV-2 infection: the tip or the iceberg? Thorax. 2020;75(8):621-2.

5. Lisboa Bastos M, Tavaziva G, Abidi SK, Campbell JR, Haraoui LP, Johnston JC, et al.

Diagnostic accuracy of serological tests for covid-19: systematic review and meta-analysis. BMJ. 2020;370:m2516.

6. Whitman JD, Hiatt J, Mowery CT, Shy BR, Yu R, Yamamoto TN, et al. Test performance evaluation of SARS-CoV-2 serological assays. medRxiv. 2020.

7. Amanat F, Stadlbauer D, Strohmeier S, Nguyen THO, Chromikova V, McMahon M, et al. A serological assay to detect SARS-CoV-2 seroconversion in humans. Nat Med. 2020;26(7):1033-6.

8. Vogl T, Leviatan S, and Segal E. SARS-CoV-2 antibody testing for estimating COVID-19 prevalence in the population. Cell Reports Medicine. 2021.

9. Peeling RW, Wedderburn CJ, Garcia PJ, Boeras D, Fongwen N, Nkengasong J, et al. Serology testing in the COVID-19 pandemic response. The Lancet Infectious Diseases. 2020;20(9):e245e9. 
medRxiv preprint doi: https://doi.org/10.1101/2021.03.16.21253716; this version posted March 20, 2021. The copyright holder for this preprint (which was not certified by peer review) is the author/funder, who has granted medRxiv a license to display the preprint in perpetuity. All rights reserved. No reuse allowed without permission.

10. Knauer MJ, Hedley BD, Bhayana V, Payne M, Chin-Yee I, and Delport J. Interim analysis of the clinical performance of five SARS-Cov-2 serology assays. Clin Biochem. 2020;86:28-30.

11. Pavlova IP, Nair SS, Kyprianou N, and Tewari AK. The Rapid Coronavirus Antibody Test: Can We Improve Accuracy? Front Med (Lausanne). 2020;7:569.

12. Li Z, Yi Y, Luo X, Xiong N, Liu Y, Li S, et al. Development and clinical application of a rapid IgM-IgG combined antibody test for SARS-CoV-2 infection diagnosis. J Med Virol. 2020.

13. Weisberg SP, Connors TJ, Zhu Y, Baldwin MR, Lin WH, Wontakal S, et al. Distinct antibody responses to SARS-CoV-2 in children and adults across the COVID-19 clinical spectrum. Nat Immunol. 2020.

14. Garcia-Beltran WF, Lam EC, Astudillo MG, Yang D, Miller TE, Feldman J, et al. COVID-19 neutralizing antibodies predict disease severity and survival. Cell. 2020;184:476-88.

15. Chang E, and Moselle KA. UK and other SARS-CoV-2-Covariants - Simulation Modeling 70\% Increase. medRxiv 2021020521251230. 2021.

16. Liu H, Zhang Q, Wei P, Chen Z, Aviszus K, Yang J, et al. The basis of a more contagious 501Y.V1 variant of SARS-COV-2. bioRxiv. 2021.

17. Lee YL, Liao CH, Liu PY, Cheng CY, Chung MY, Liu CE, et al. Dynamics of anti-SARSCov-2 IgM and IgG antibodies among COVID-19 patients. $J$ Infect. 2020;81(2):e55-e8.

18. Gaebler C, Wang Z, Lorenzi JCC, Muecksch F, Finkin S, Tokuyama M, et al. Evolution of antibody immunity to SARS-CoV-2. Nature. 2021:doi: 10.1038/s41586-021-03207-w.

19. Li Y, Lai DY, Zhang HN, Jiang HW, Tian X, Ma ML, et al. Linear epitopes of SARS-CoV-2 spike protein elicit neutralizing antibodies in COVID-19 patients. Cell Mol Immunol. 2020;17(10):1095-7.

20. Shrock E, Fujimura E, Kula T, Timms RT, Lee IH, Leng Y, et al. Viral epitope profiling of COVID-19 patients reveals cross-reactivity and correlates of severity. Science. 2020;370(6520).

21. Lucchese G. Epitopes for a 2019-nCoV vaccine. Cell Mol Immunol. 2020;17(5):539-40.

22. Ladner JT, Henson SN, Boyle AS, Engelbrektson AL, Fink ZW, Rahee F, et al. Epitoperesolved profiling of the SARS-CoV-2 antibody response identifies cross-reactivity with endemic human coronaviruses. Cell Rep Med. 2021;2(1):100189.

23. Barnes CO, West AP, Jr., Huey-Tubman KE, Hoffmann MAG, Sharaf NG, Hoffman PR, et al. Structures of Human Antibodies Bound to SARS-CoV-2 Spike Reveal Common Epitopes and Recurrent Features of Antibodies. Cell. 2020;182(4):828-42 e16. 
medRxiv preprint doi: https://doi.org/10.1101/2021.03.16.21253716; this version posted March 20, 2021. The copyright holder for this preprint (which was not certified by peer review) is the author/funder, who has granted medRxiv a license to display the preprint in perpetuity.

24. Wang H, Wu X, Zhang X, Hou X, Liang T, Wang D, et al. SARS-CoV-2 Proteome Microarray for Mapping COVID-19 Antibody Interactions at Amino Acid Resolution. ACS Cent Sci. 2020;6(12):2238-49.

25. Grifoni A, Sidney J, Zhang Y, Scheuermann RH, Peters B, and Sette A. A Sequence Homology and Bioinformatic Approach Can Predict Candidate Targets for Immune Responses to SARSCoV-2. Cell Host Microbe. 2020;27(4):671-80 e2.

26. Cai Y, Zhang J, Xiao T, Peng H, Sterling SM, Walsh RM, Jr., et al. Distinct conformational states of SARS-CoV-2 spike protein. Science. 2020;369(6511):1586-92.

27. Li Q, Wu J, Nie J, Zhang L, Hao H, Liu S, et al. The Impact of Mutations in SARS-CoV-2 Spike on Viral Infectivity and Antigenicity. Cell. 2020;182(5):1284-94 e9.

28. Gupta A, and Chaudhary VK. Whole-blood agglutination assay for on-site detection of human immunodeficiency virus infection. J Clin Microbiol. 2003;41(7):2814-21.

29. Abe KT, Li Z, Samson R, Samavarchi-Tehrani P, Valcourt EJ, Wood H, et al. A simple protein-based surrogate neutralization assay for SARS-CoV-2. JCI Insight. 2020;5(19).

30. Salazar E, Kuchipudi SV, Christensen PA, Eagar T, Yi X, Zhao P, et al. Convalescent plasma anti-SARS-CoV-2 spike protein ectodomain and receptor-binding domain IgG correlate with virus neutralization. J Clin Invest. 2020;130(12):6728-38.

31. Boonyaratanakornkit J, Morishima C, Selke S, Zamora D, McGuffin S, Shapiro AE, et al. Clinical, laboratory, and temporal predictors of neutralizing antibodies against SARS-CoV-2 among COVID-19 convalescent plasma donor candidates. J Clin Invest. 2021;131(3).

32. Arvin AM, Fink K, Schmid MA, Cathcart A, Spreafico R, Havenar-Daughton C, et al. A perspective on potential antibody-dependent enhancement of SARS-CoV-2. Nature. 2020;584(7821):353-63.

33. Jiang HW, Li Y, Zhang HN, Wang W, Yang X, Qi H, et al. SARS-CoV-2 proteome microarray for global profiling of COVID-19 specific IgG and IgM responses. Nat Commun. 2020;11(1):3581.

34. Thomson EC, Rosen LE, Shepherd JG, Spreafico R, da Silva Filipe A, Wojcechowskyj JA, et al. Circulating SARS-CoV-2 spike N439K variants maintain fitness while evading antibodymediated immunity. Cell. 2021.

35. Yao W, Wang Y, Ma D, Tang X, Wang H, Li C, et al. bioRxiv 20210127428353. 2021.

36. Rees-Spear C, Muir L, Griffith SA, Heaney J, Aldon Y, Snitselaar JL, et al. bioRxiv 20210115426849. 2021. 
medRxiv preprint doi: https://doi.org/10.1101/2021.03.16.21253716; this version posted March 20, 2021. The copyright holder for this preprint (which was not certified by peer review) is the author/funder, who has granted medRxiv a license to display the preprint in perpetuity. All rights reserved. No reuse allowed without permission.

37. Tada T, Dcosta BM, Samanovic-Golden M, Herati RS, Cornelius A, Mulligan MJ, et al. Neutralization of viruses with European, South African, and United States SARS-CoV-2 variant spike proteins by convalescent sera and BNT162b2 mRNA vaccine-elicited antibodies. bioRxiv. 2021.

38. Stamatatos L, Czartoski J, Wan Y-H, Homad LJ, Rubin V, Glantz H, et al. bioRxiv 20201014340034.2021.

39. Shen X, Tang H, McDanal C, Wagh K, Fischer W, Theiler J, et al. SARS-CoV-2 variant B.1.1.7 is susceptible to neutralizing antibodies elicited by ancestral Spike vaccines. bioRxiv. 2021.

40. Hsieh CL, Goldsmith JA, Schaub JM, DiVenere AM, Kuo HC, Javanmardi K, et al. Structurebased design of prefusion-stabilized SARS-CoV-2 spikes. Science. 2020;369(6510):1501-5.

41. Perveen S, Yazdi AK, Devkota K, Li F, Ghiabi P, Hajian T, et al. A high throughput RNA displacement assay for screening SARS-CoV-2 nsp10-nsp16 complex towards developing therapeutics for COVID-19. bioRxiv. 2020:2020.10.14.340034.

42. Schneider CA, Rasband WS, and Eliceiri KW. NIH Image to ImageJ: 25 years of image analysis. Nat Methods. 2012;9(7):671-5. 
medRxiv preprint doi: https://doi.org/10.1101/2021.03.16.21253716; this version posted March 20, 2021. The copyright holder for this preprint

(which was not certified by peer review) is the author/funder, who has granted medRxiv a license to display the preprint in perpetuity.

All rights reserved. No reuse allowed without permission.

\section{FIGURE LEGENDS}

Figure 1. Lack of correlation between $\mathrm{S} / \mathrm{N}$ antibody response and disease severity or outcome. (A) Layout of the proteome array. (B) Representative images of antibody responses for COVID-19 patients with moderate or severe disease determined using the proteome array. (C) Dynamic IgG antibody profiles for two patients with severe or fatal disease on days 1, 7 and 10 of ICU admission. (D, E) Prevalence of antibody responses to the $\mathrm{S}$ or $\mathrm{N}$ protein/domain for the indicated patient groups. $(\mathbf{F}, \mathbf{G})$ The intensity of antibody response to the $\mathrm{S}$ or $\mathrm{N}$ protein/domain is not correlated with disease severity $(\mathbf{F})$ or outcome $(\mathbf{G})$. NS, not significant; based on unpaired Student's t-test with Welch's correction.

\section{Figure 2. Identification of SARS-CoV-2 epitopes and epitope-resolved antibody profiling.}

(A) Workflow for identifying antigenic epitopes by peptide arrays and the layout of a master array for SARS-CoV-2 antibody profiling. (B, C) Representative images of epitope-resolved antibody profiles for the different groups of COVID-19 patients.

\section{Figure 3. Epitope-specific antibody response distinguish COVID-19 patients with disparate} disease severity and outcome. (A) Antibodies from patients with severe disease $(n=34)$ recognized significantly more epitopes than those with moderate conditions $(n=31)$. (B) Distribution of epitopes in moderate vs. severe cases. (C) Number of epitopes/patient in the alive $(n=51)$ vs. fatal $(n=14)$ groups. (D) Distribution of epitopes in alive vs. fatal cases. (E) Heatmap representation of epitope-specific antibodies detected by the master array. Note that only cases with at least one epitope producing $\operatorname{IgG}$ binding signal greater than 1000 were included in the heatmap. (F) Fatal cases showed significantly stronger antibody responses for the S-811 and S-881 epitopes. *, ${ }^{*}<0.05 ; * *, p<0.002$; NS, not significant; unpaired Student's t-test with Welch's correction. (G) Structure models to show location of the critical epitopes on the Spike protein. The epitopes S-671, S-811 and S-881 are shown on the domain structure diagram of Spike as well as its prefusion (left) and post-fusion (right) conformation. The S protein has two cleavage sites, S1/S2 and S2'. The S-671 epitope is located at the C-terminus of $\mathrm{S} 1$, and it is disordered in the prefusion cryo-EM structure (left panel: PDB 6XR8). A homology model from the SWISS-MODEL repository was employed to draw an S-671 epitope model in the left panel (colored blue), without cleavage at S1/S2. The Pro681 site is shown with a red sphere. The S2' cleavage site is located on the S-811 epitope. The S-881 epitope is buried and inaccessible in the prefusion state. However, the region (fusion peptide or FP) targets the host cell membrane and is fully 
medRxiv preprint doi: https://doi.org/10.1101/2021.03.16.21253716; this version posted March 20, 2021. The copyright holder for this preprint (which was not certified by peer review) is the author/funder, who has granted medRxiv a license to display the preprint in perpetuity.

All rights reserved. No reuse allowed without permission.

disordered in the post-fusion conformation (right panel: PDB 6XRA, residues 771-911 are disordered). The S1 region is colored orange, except for RBD in cyan. The region between S1/S2 cleavage and S2' cleavage sites is in green. The S-811 and S-881 epitopes are colored magenta in the prefusion conformation.

Figure 4. SARS-CoV-2 variants feature mutated epitopes not recognized by antibodies specific for the corresponding wt epitopes. (A) Layout of a SARS-CoV-2 variant epitope array. (B) Examples of COVID-19 cases that showed distinct IgG responses to the mutated and wt epitopes (boxed). (C) Dilution series of P681/P681H-containing epitopes demonstrating the loss of binding for the mutant epitopes.

\section{Figure 5. Rapid epitope-dependent agglutination assay for SARS-CoV-2 antibodies effectively} differentiate patient groups. (A) Latex bead agglutination assay to gauge antibody response to SARS-CoV-2. The latex beads were coated with one or more biotinylated S or $\mathrm{N}$ epitope peptides and mixed with SARS-CoV-2 -negative (COVID-, top) or -positive (COVID+, bottom) plasma. The presence of antibodies against the epitopes promoted the agglutination of the latex beads. Images shown were taken after 2 min incubation at room temperature. (B) Epitope-based latex agglutination assay distinguished COVID-19+ from COVID-19- or preCOVID-19 plasma. The epitope peptides used were: S-811 and S-1146 from the spike and N-156 and N-361 from the nucleocapsid protein. (C) Correlation of disease severity with antibody responses to the S-811, N-156 and N-361 determined by latex bead agglutination. (D) Correlation of disease outcome with antibody responses to the S-551, S$811, \mathrm{~S}-881$ and N-156 epitopes determined by latex bead agglutination. P values calculated based on unpaired Student t-test with Welch's correction (no assumption of equal SD) (n=20 for B; $\mathrm{n}=10$ for C $\&$ D). ${ }^{*} p<0.05, * * p<0.002$.

Figure 6. Antibody specificity predicts neutralization efficiency and disease outcome. (A) Correlation of neutralization efficiency with clinical severity (left) or outcome (right). *, p<0.05; **, $\mathrm{p}<0.01$. (B) Correlation of S-RBD-antibody response measured by latex agglutination with COVID19 severity (left) or outcome (right). ${ }^{* *}, \mathrm{p}<0.01$. (C) Pearson (r) correlation between epitopedependent agglutination and neutralization. Confidence interval (CI): 95\%. P values were based on one-way ANOVA with Geisser-Green house correction (no assumption of equal variability of difference) ( $\mathrm{n}=20$ for $\mathrm{A}$, except $\mathrm{n}=14$ for fatal; $\mathrm{n}=10$ for $\mathrm{B} \& \mathrm{C})$. 
Table 1. Spike and Nucleocapsid epitopes identified and characterized in this study

\begin{tabular}{|c|c|c|c|c|}
\hline Protein & Residues & Epitope & Epitope Sequence & $\begin{array}{c}\text { Epitope } \\
\text { Intensity }\end{array}$ \\
\hline Spike & $21-35$ & *S-21 & RTQLPPAYTNSFTRG & \multirow{3}{*}{ Medium } \\
\hline Spike & $31-45$ & S-31 & SFTRGVYYPDKVFRS & \\
\hline Spike & $36-50$ & S-36 & VYYPDKVFRSSVLHS & \\
\hline Spike & $176-190$ & *S-176 & LMDLEGKQGNFKNLR & Medium \\
\hline Spike & $451-465$ & *S-451 & YLYRLFRKSNLKPFE & \multirow{3}{*}{ Weak } \\
\hline Spike & $456-470$ & S-456 & FRKSNLKPFERDIST & \\
\hline Spike & $471-485$ & S-471 & EIYQAGSTPCNGVEG & \\
\hline Spike & $545-565$ & S-545 & GLTGTGVLTESNKKFLPFQQF & \multirow{6}{*}{ Weak } \\
\hline Spike & $551-565$ & *S-551 & VLTESNKKFLPFQQF & \\
\hline Spike & $556-570$ & S-556 & NKKFLPFQQFGRDIA & \\
\hline Spike & $566-587$ & S-566 & GRDIADTTDAVRDPQTLEILDI & \\
\hline Spike & $571-585$ & S-571 & DTTDAVRDPQTLEIL & \\
\hline Spike & $576-590$ & S-576 & VRDPQTLEILDITPC & \\
\hline Spike & $621-635$ & S-621 & PVAIHADQLTPTWRV & \multirow{3}{*}{ Weak } \\
\hline Spike & $624-640$ & S-646 & IHADQLTPTWRVYSTGS & \\
\hline Spike & $626-640$ & S-626 & ADQLTPTWRVYSTGS & \\
\hline Spike & $661-675$ & S-661 & ECDIPIGAGICASYQ & \multirow{3}{*}{ Strong } \\
\hline Spike & $671-685$ & *S-671 & CASYQTQTNSPRRAR & \\
\hline Spike & $676-690$ & S-676 & TQTNSPRRARSVASQ & \\
\hline Spike & $691-705$ & S-691 & SIIAYTMSLGAENSV & \multirow{2}{*}{ Medium } \\
\hline Spike & $696-710$ & S-696 & TMSLGAENSVAYSNN & \\
\hline Spike & $796-810$ & S-796 & DFGGFNFSQILPDPS & Strong \\
\hline Spike & $811-825$ & *S-811 & KPSKRSFIEDLLFNK & \multirow{2}{*}{ Strong } \\
\hline Spike & $816-830$ & S-816 & SFIEDLLFNKVTLAD & \\
\hline Spike & $881-895$ & ${ }^{*} S-881$ & TITSGWTFGAGAALQ & Strong \\
\hline Spike & $\begin{array}{l}1146- \\
1160\end{array}$ & *S-1146 & DSFKEELDKYFKNHT & Strong \\
\hline Spike & $\begin{array}{l}1166- \\
1180\end{array}$ & ${ }^{*} S-1166$ & LGDISGINASVVNIQ & Weak \\
\hline Spike & $\begin{array}{l}1216- \\
1230\end{array}$ & *S-1216 & IWLGFIAGLIAIVMV & Weak \\
\hline Nucleocapsid & $1-15$ & $\mathrm{~N}-1$ & MSDNGPQNQRNAPRI & \multirow{2}{*}{ Weak } \\
\hline Nucleocapsid & $6-20$ & ${ }^{*} \mathrm{~N}-6$ & PQNQRNAPRITFGGP & \\
\hline Nucleocapsid & $31-45$ & $\mathrm{~N}-31$ & ERSGARSKQRRPQGL & Weak \\
\hline
\end{tabular}




\begin{tabular}{|c|c|c|c|c|}
\hline Nucleocapsid & $36-50$ & $\mathrm{~N}-36$ & RSKQRRPQGLPNNTA & \\
\hline Nucleocapsid & $41-55$ & $\mathrm{~N}-41$ & RPQGLPNNTASWFTA & \\
\hline Nucleocapsid & $146-160$ & $\mathrm{~N}-146$ & IGTRNPANNAAIVLQ & \multirow{4}{*}{ Strong } \\
\hline Nucleocapsid & $153-171$ & ${ }^{* *} \mathrm{~N}-153$ & NNNAATVLQLPQGTTLPKG & \\
\hline Nucleocapsid & $156-170$ & ${ }^{*} \mathrm{~N}-156$ & AIVLQLPQGTTLPKG & \\
\hline Nucleocapsid & $161-175$ & $\mathrm{~N}-161$ & LPQGTTLPKGFYAEG & \\
\hline Nucleocapsid & $191-205$ & $\mathrm{~N}-191$ & RNSSRNSTPGSSRGT & \multirow{3}{*}{ Weak } \\
\hline Nucleocapsid & $196-210$ & $\mathrm{~N}-196$ & NSTPGSSRGTSPARM & \\
\hline Nucleocapsid & $201-215$ & $\mathrm{~N}-201$ & SSRGTSPARMAGNGG & \\
\hline Nucleocapsid & $221-235$ & ${ }^{*} \mathrm{~N}-221$ & LLLLDRLNQLESKMS & \multirow{6}{*}{ Medium } \\
\hline Nucleocapsid & $231-245$ & $\mathrm{~N}-231$ & ESKMSGKGQQQQGQT & \\
\hline Nucleocapsid & $236-250$ & $\mathrm{~N}-236$ & GKGQQQQGQTVTKKS & \\
\hline Nucleocapsid & $241-255$ & $\mathrm{~N}-241$ & QQGQTVTKKSAAEAS & \\
\hline Nucleocapsid & $246-260$ & ${ }^{*} \mathrm{~N}-246$ & VTKKSAAEASKKPRQ & \\
\hline Nucleocapsid & $251-265$ & $\mathrm{~N}-251$ & AAEASKKPRQKRTAT & \\
\hline Nucleocapsid & $355-375$ & $\mathrm{~N}-355$ & KHIDAYKTFPPTEPKKDKKKK & \multirow{8}{*}{ Strong } \\
\hline Nucleocapsid & $361-375$ & ${ }^{*} \mathrm{~N}-361$ & KTFPPTEPKKDKKKK & \\
\hline Nucleocapsid & $366-380$ & $\mathrm{~N}-366$ & TEPKKDKKKKADETQ & \\
\hline Nucleocapsid & $368-391$ & ${ }^{* *} \mathrm{~N}-368$ & PKKDKKKKTDEAQPLPQRQKKQP & \\
\hline Nucleocapsid & $371-385$ & $\mathrm{~N}-371$ & DKKKKADETQALPQR & \\
\hline Nucleocapsid & $381-395$ & ${ }^{*} \mathrm{~N}-381$ & ALPQRQKKQQTVTLL & \\
\hline Nucleocapsid & $381-401$ & $* * \mathrm{~N}-381$ & QPLPQRQKKQPTVTLLPAADM & \\
\hline Nucleocapsid & $386-400$ & $\mathrm{~N}-386$ & QKKQQTVTLLPAADL & \\
\hline
\end{tabular}

* Master array peptide; ** Sequence based on SARS-CoV residues Strong: average epitope intensity $>20,000$

Medium: average epitope intensity 10,000-20,000

Weak: average epitope intensity $<10,000$ 
Table 2. A list of $\mathrm{S}$ and $\mathrm{N}$ mutations examined by the variant epitope peptide array

\begin{tabular}{|c|c|c|c|c|}
\hline Protein & $\begin{array}{l}\text { Mutation and } \\
\text { (Source) }\end{array}$ & Epitope Sequence & $\begin{array}{c}\text { Overlap with } \\
\text { Identified Epitope }\end{array}$ & $\begin{array}{c}\text { Mutation Disrupts } \\
\text { Binding }\end{array}$ \\
\hline Spike & HV 69-70 deletion (\#) & TWFHAI[HVID]SGTNGTK & $\mathrm{N}$ & - \\
\hline Spike & Y144 deletion (\#) & NDPFLGV[YIL]YHKNNKS & $\mathrm{N}$ & - \\
\hline Spike & A570D (\#) & QQFGRDI[A/D]DTTDAVR & S-556; S-566 & ND \\
\hline Spike & $\mathrm{P} 681 \mathrm{H}(\#)$ & CASYQTQTNS[P/H]RRAR & *S-671; S-676 & $\mathbf{Y}$ \\
\hline Spike & P681H (centred) (\#) & YQTQTNS[P/H]RRARSVA & *S-671; S-676 & $\mathbf{Y}$ \\
\hline Spike & T716I (\#) & NNSIAIP[T/I]NFTISVT & $\mathrm{N}$ & - \\
\hline Spike & S982A (\#) & SVLNDIL[S/A]RLDKVEA & $\mathrm{N}$ & - \\
\hline Spike & $\mathrm{D} 1118 \mathrm{H}(\#)$ & EPQIITT[D/H]NTFVSGN & $\mathrm{N}$ & - \\
\hline Spike & N501Y (\# \&) & SYGFQPT[N/Y]GVGYQPY & $\mathrm{N}$ & - \\
\hline Spike & E484K (\&) & STPCNGV[E/K]GFNCYFP & S-471 & ND \\
\hline Spike & K417N (\&) & IAPGQTG[K/N]IADYNYK & $\mathrm{N}$ & - \\
\hline Spike & D614G (+) & QVAVLYQ[D/G]VNCTEVP & $\mathrm{N}$ & - \\
\hline Spike & $\mathrm{A} 831 \mathrm{~V}(+)$ & NKVTLAD[A/V]GFIKQYG & $\mathrm{N}$ & - \\
\hline Spike & N439K (+) & CVIAWNS[N/K]NLDSKVG & $\mathrm{N}$ & - \\
\hline Spike & N709Q (+) & ENSVAYS[N/Q]NSIAIPT & S-696 & ND \\
\hline Spike & $\mathrm{A} 522 \mathrm{~V}(+)$ & FELLHAP[A/V]TVCGPKK & $\mathrm{N}$ & - \\
\hline Spike & V483A (+) & GSTPCNG[VIA]EGFNCYF & S-471 & ND \\
\hline Spike & L452R (+) & VGGNYNY[L/R]YRLFRKS & ${ }^{*} S-451$ & ND \\
\hline Spike & $\mathrm{A} 475 \mathrm{~V}(+)$ & ISTEIYQ[A/V]GSTPCNG & S-471 & ND \\
\hline Spike & $\mathrm{N} 234 \mathrm{Q}(+)$ & VDLPIGI[N/Q]ITRFQTL & $\mathrm{N}$ & - \\
\hline Spike & $\mathrm{F} 490 \mathrm{~L}(+)$ & VEGFNCY[F/L]PLQSYGF & $\mathrm{N}$ & - \\
\hline Spike & V367F (+) & NCVADYS[V/F]LYNSASF & $\mathrm{N}$ & - \\
\hline Spike & Q414E (+) & VRQIAPG[Q/E]TGKIADY & $\mathrm{N}$ & - \\
\hline Spike & Y508H (+) & NGVGYQP[Y/H]RVVVLSF & $\mathrm{N}$ & - \\
\hline Spike & 1468F/T (+) & LKPFERD[I/F/T]STEIYQA & S-456 & ND \\
\hline Spike & N165Q (+) & RVYSSAN[N/Q]CTFEYVS & $\mathrm{N}$ & - \\
\hline Nucleocapsid & D3L (\#) & MS[D/L]NGPQNQRNAPRI & $\mathrm{N}-1$ & $\mathrm{Y}$ \\
\hline Nucleocapsid & S235F (\#) & NQLESKM[S/F]GKGQQQQ & *N-221; N-231 & $\mathbf{Y}$ \\
\hline
\end{tabular}

Footnote: Bold letter denotes site of mutation. * master array peptide; ND: binding not detected on variant array. \# UK Variant B.1.1.7; \& South African Variant 501.V2; + Li et al (19) 
A

\begin{tabular}{|c|c|c|c|c|c|c|c|}
\hline $\lg$ & PBS & $\begin{array}{c}\text { S- } \\
\text { RBD }\end{array}$ & PBS & $\begin{array}{c}\text { S- } \\
\text { Ecto }\end{array}$ & $\begin{array}{l}\text { PBS } \\
\text { NSP3 }\end{array}$ & $\begin{array}{c}\text { NSP3 } \\
\text { unique }\end{array}$ & ADRP \\
\hline $\lg$ & $\begin{array}{l}\text { NSP3 } \\
\text { PLLF }\end{array}$ & $\begin{array}{c}\text { NSP } \\
\text { NAB }\end{array}$ & $\begin{array}{c}\text { NSP } \\
4\end{array}$ & $\begin{array}{c}\text { NSP } \\
5\end{array}$ & $\begin{array}{c}\text { NSP } \\
7\end{array}$ & $\begin{array}{c}\text { NSP } \\
8\end{array}$ & $\begin{array}{c}\text { NSP } \\
9\end{array}$ \\
\hline $\lg$ & $\begin{array}{c}\text { NSP } \\
10\end{array}$ & $\begin{array}{c}\text { NSP } \\
16\end{array}$ & PBS & $\begin{array}{c}\text { N- } \\
\text { FL }\end{array}$ & PBS & $\begin{array}{c}\text { N- } \\
\text { iimer }\end{array}$ & $\begin{array}{c}\text { N- } \\
\text { RBD }\end{array}$ \\
\hline
\end{tabular}

B
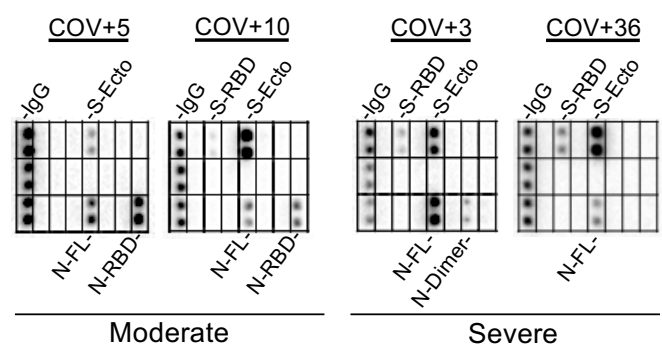

$\mathrm{D}$

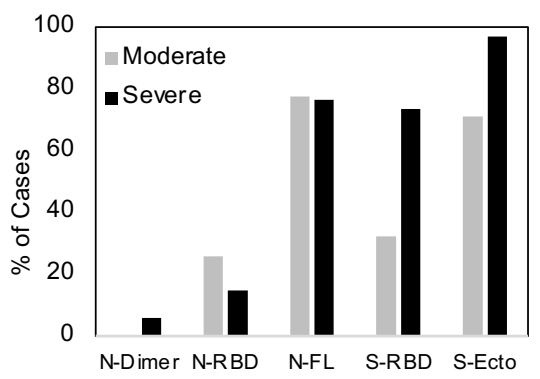

C $\frac{\text { COV }+44}{\text { (Alive) }}$
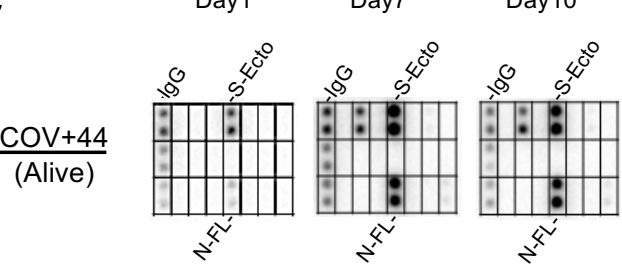

$\underline{\mathrm{COV}+47}$
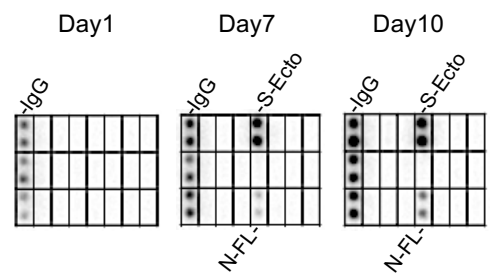

$E$

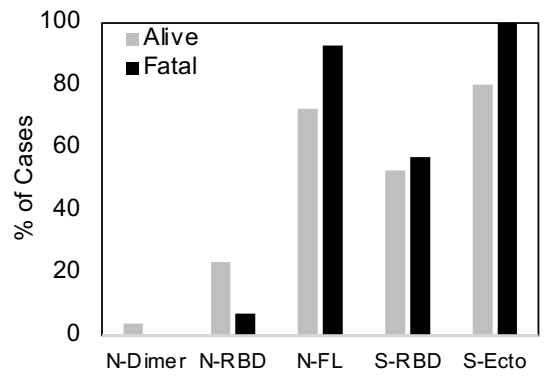

$\mathrm{F}$
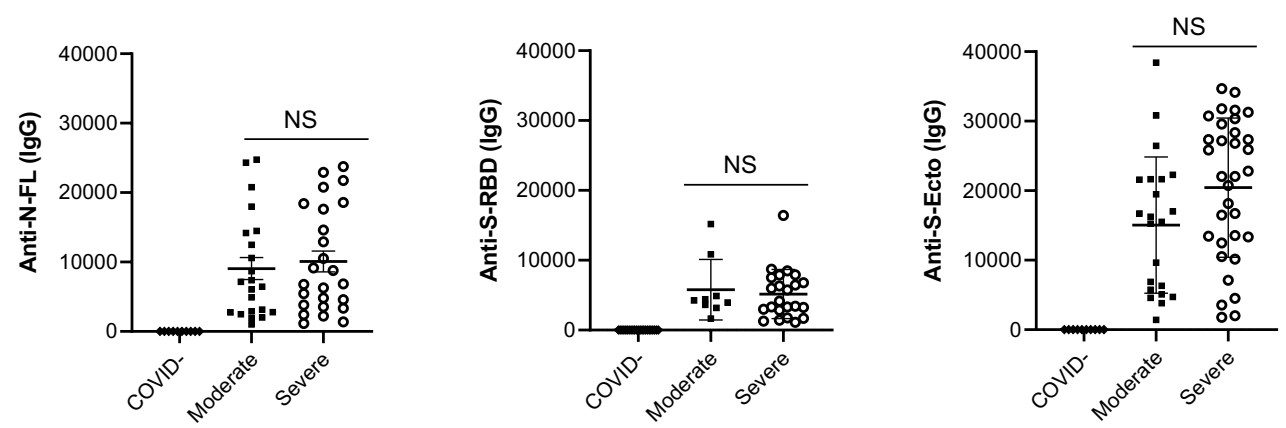

G
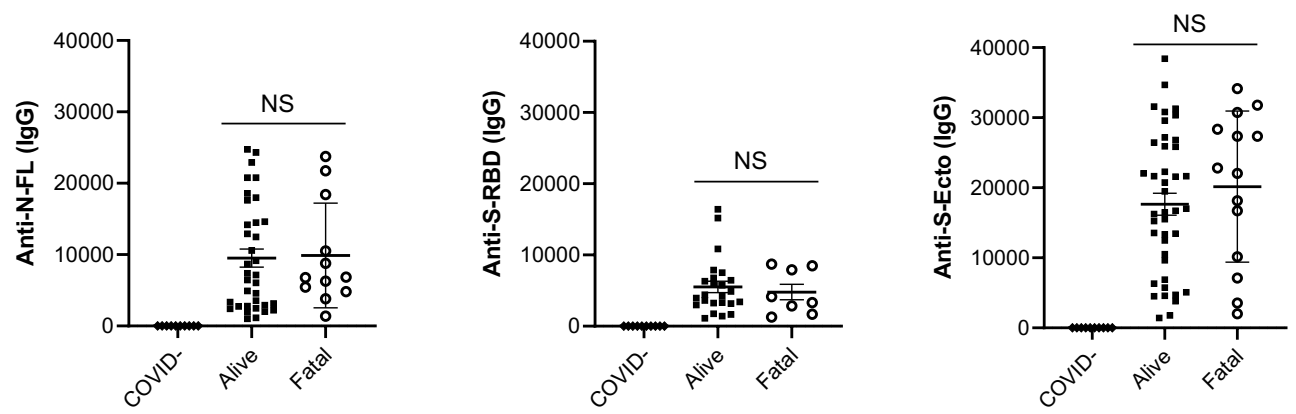

Fig. 1. Lack of correlation between $\mathbf{S} / \mathrm{N}$ antibody response and disease severity or outcome. (A) Layout of the proteome array. (B) Representative images of antibody responses for COVID-19 patients with moderate or severe disease determined using the proteome array. (C) Dynamic IgG antibody profiles for two patients with severe or fatal disease on days 1,7 and 10 of ICU admission. (D, E) Prevalence of antibody responses to the $S$ or $\mathrm{N}$ protein/domain for the indicated patient groups. $(\mathbf{F}, \mathbf{G})$ The intensity of antibody response to the $\mathrm{S}$ or $\mathrm{N}$ protein/domain is not correlated with disease severity (F) or outcome (G). NS, not significant; based on unpaired Student's t-test with Welch's correction. 
medRxiv preprint doi: https://doi.org/10.1101/2021.03.16.21253716; this version posted March 20, 2021. The copyright holder for this preprint (which was not certified by peer review) is the author/funder, who has granted medRxiv a license to display the preprint in perpetuity. All rights reserved. No reuse allowed without permission.

A

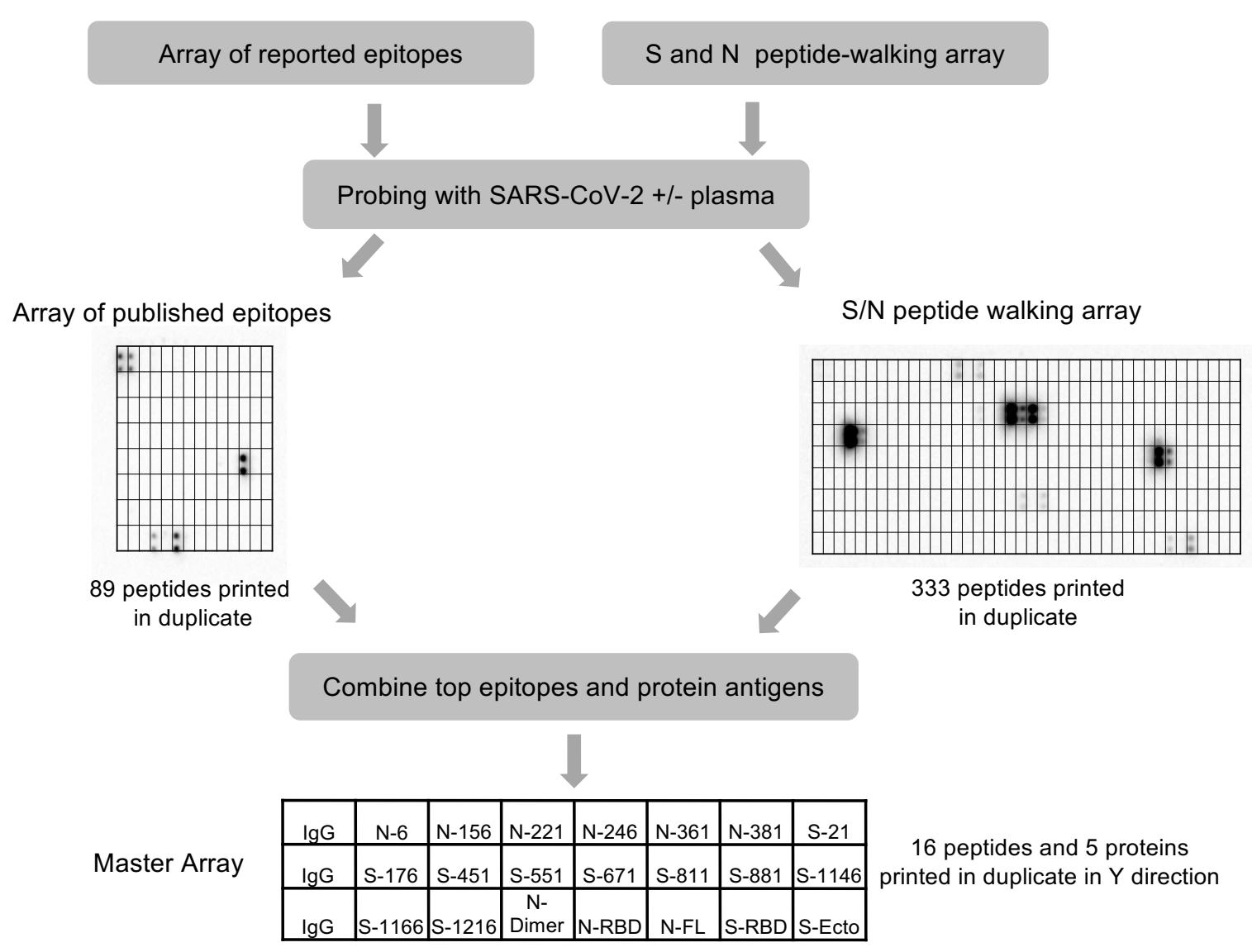

B
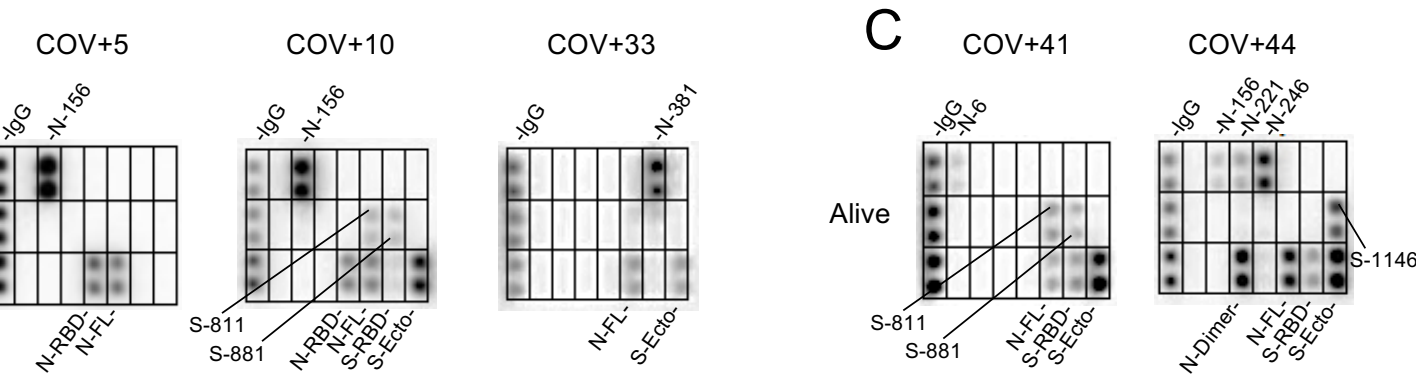

$\mathrm{COV}+48$

Moderate

$\mathrm{cov}+3$

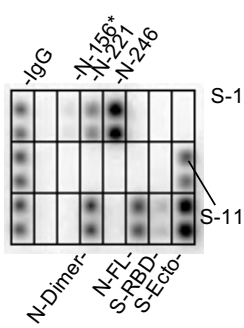

$\mathrm{COV}+12$

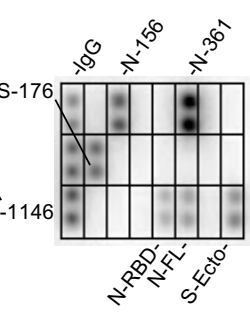

$\mathrm{COV}+20$

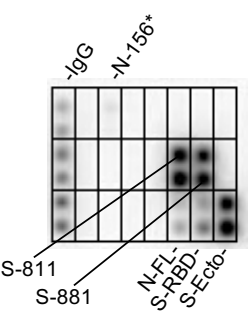

$$
\mathrm{COV}+36
$$

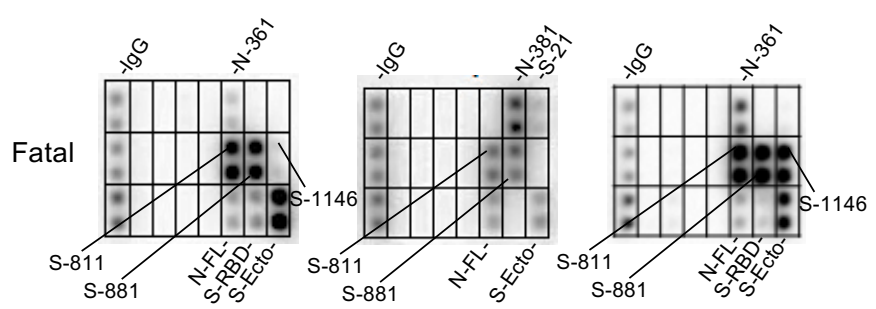

Fig. 2. Identification of SARS-CoV-2 epitopes and epitope-resolved antibody profiling.

(A) Workflow for identifying antigenic epitopes by peptide arrays and the layout of a master array for SARS-CoV-2 antibody profiling. (B, C) Representative images of epitope-resolved antibody profiles for the different groups of COVID-19 patients. 
medRxiv preprint doi: https://doi.org/10.1101/2021.03.16.21253716; this version posted March 20, 2021. The copyright holder for this preprint (which was not certified by peer review) is the author/funder, who has granted medRxiv a license to display the preprint in perpetuity. All rights reserved. No reuse allowed without permission.

A

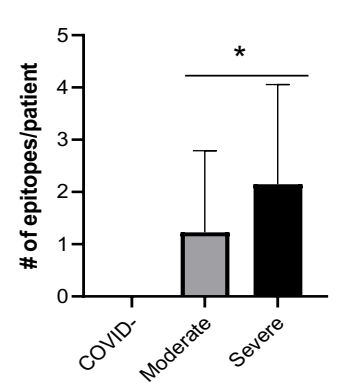

C

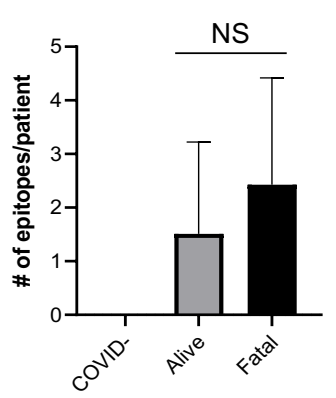

$\mathrm{E}$

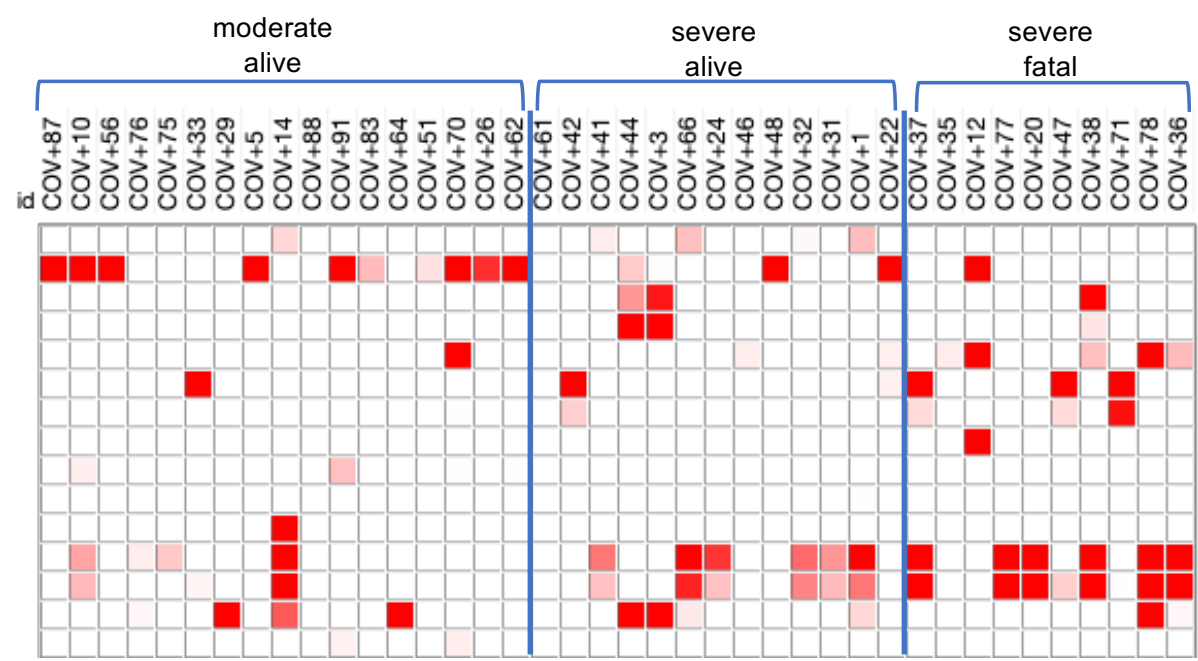

B

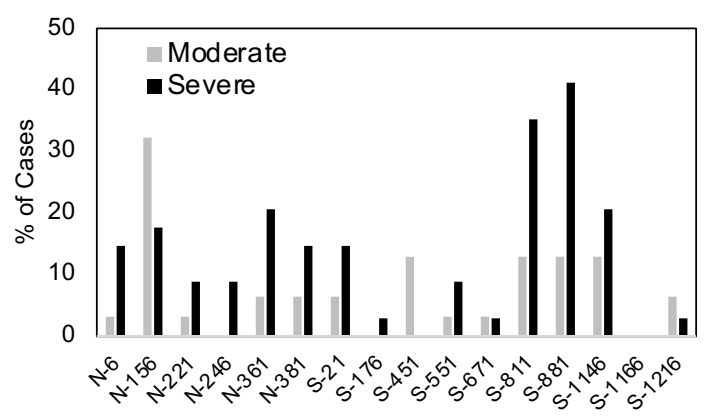

D

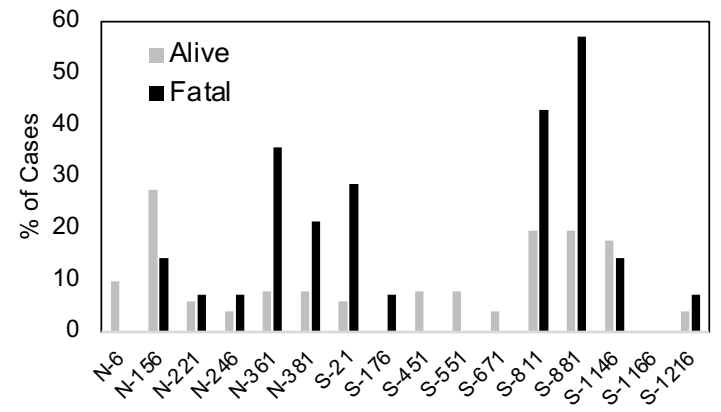

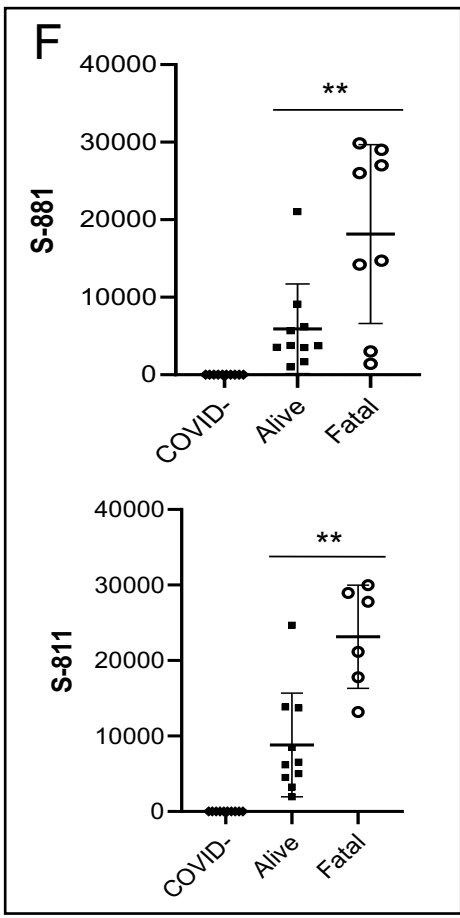

G

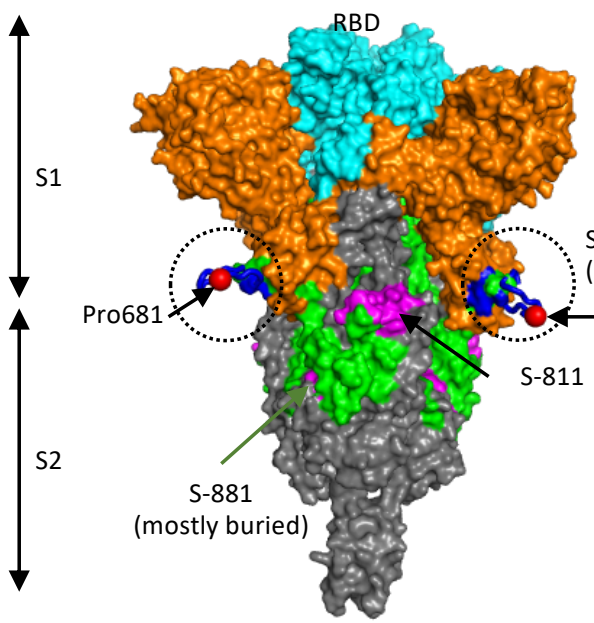

prefusion conformation (PDB: 6XR8)
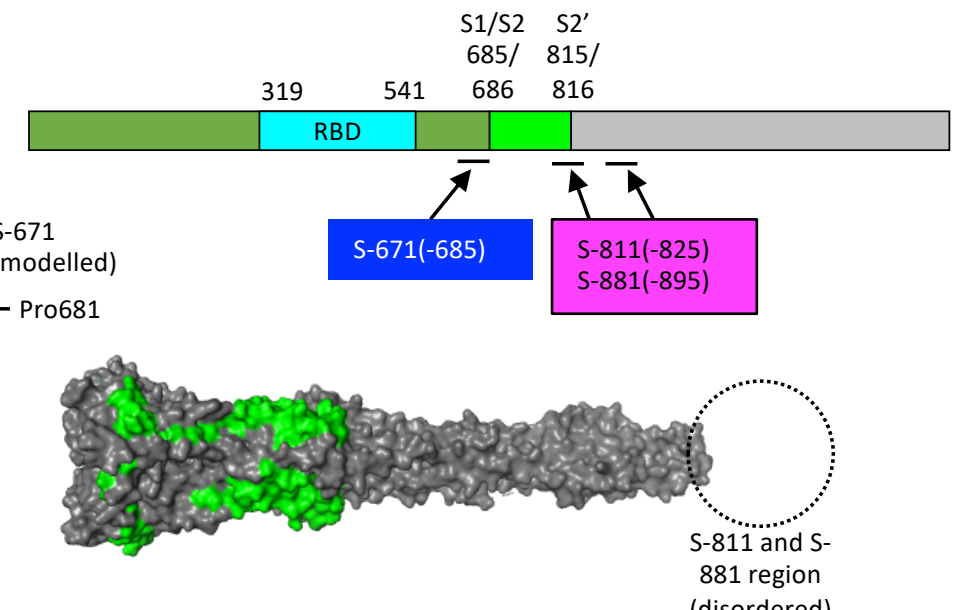

S2 postfusion conformation (PDB: 6XRA)

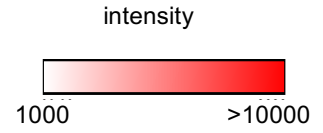

S-21

S-176

S-551

S-671

S-811

S-881 U

S-1146

S-1216

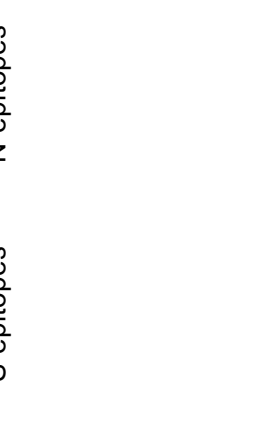


Figure 3. Epitope-specific antibody response distinguish COVID-19 patients with disparate disease severity and outcome. (A) Antibodies from patients with severe disease $(n=34)$ recognized significantly more epitopes than those with moderate conditions $(n=31)$. (B) Distribution of epitopes in moderate vs. severe cases. (C) Number of epitopes/patient in the alive $(n=51)$ vs. fatal $(n=14)$ groups. (D) Distribution of epitopes in alive vs. fatal cases. (E) Heatmap representation of epitope-specific antibodies detected by the master array. Note that only cases with at least one epitope producing IgG binding signal greater than 1000 were included in the heatmap. (F) Fatal cases showed significantly stronger antibody responses for the S-811 and S-881 epitopes. *, $p<0.05$; ${ }^{* *}, \mathrm{p}<0.002$; NS, not significant; unpaired Student's t-test with Welch's correction. (G) Structure models to show location of the critical epitopes on the Spike protein. The epitopes S-671, S-811 and S-881 are shown on the domain structure diagram of Spike as well as its prefusion (left) and postfusion (right) conformation. The S protein has two cleavage sites, S1/S2 and S2'. The S-671 epitope is located at the $\mathrm{C}$-terminus of $\mathrm{S} 1$, and it is disordered in the prefusion cryo-EM structure (left panel: PDB 6XR8). A homology model from the SWISS-MODEL repository was employed to draw an S671 epitope model in the left panel (colored blue), without cleavage at S1/S2. The Pro681 site is shown with a red sphere. The S2' cleavage site is located on the S-811 epitope. The S-881 epitope is buried and inaccessible in the prefusion state. However, the region (fusion peptide or FP) targets the host cell membrane and is fully disordered in the post-fusion conformation (right panel: PDB 6XRA, residues 771-911 are disordered). The $\mathrm{S} 1$ region is colored orange, except for RBD in cyan. The region between S1/S2 cleavage and S2' cleavage sites is in green. The S-811 and S-881 epitopes are colored magenta in the prefusion conformation. 
medRxiv preprint doi: https://doi.org/10.1101/2021.03.16.21253716; this version posted March 20, 2021. The copyright holder for this preprint (which was not certified by peer review) is the author/funder, who has granted medRxiv a license to display the preprint in perpetuity.

All rights reserved. No reuse allowed without permission.

A

\begin{tabular}{|c|c|c|c|c|c|c|c|c|c|c|c|c|c|c|c|}
\hline IgG & N165Q & N165 & N234Q & N234 & V367F & V367 & Q414E & Q414 & N439K & N439 & L452R & L452 & I468F & I468T & I468 \\
\hline IgG & A475V & A475 & V483A & V483 & F490L & F490 & Y508H & Y508 & A522V & A522 & D614G & D614 & N709Q & N709 & PBS \\
\hline IgG & A831V & A831 & PBS & PBS & K417N & K417 & E484K & E484 & PBS & $\begin{array}{c}\text { HV69- } \\
\text { 70del }\end{array}$ & HV69-70 & N:D3L & N:D3 & S235 & N: S235 \\
\hline IgG & PBS & Y144del & Y144 & N501Y & N501 & A570D & A570 & T7161 & T716 & S982A & S982 & D1118H & D1118 & P681H & P681 \\
\hline
\end{tabular}

B

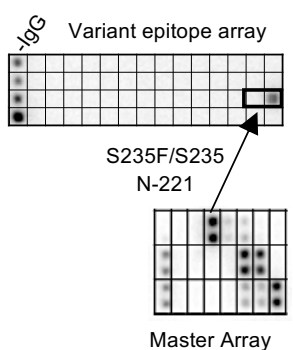

$\underline{\mathrm{COV}+38}$

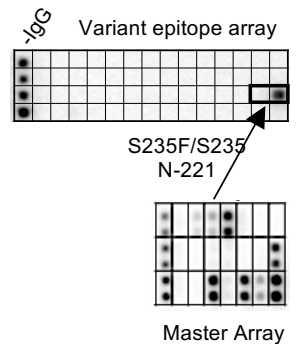

$\underline{\mathrm{COV}+44}$

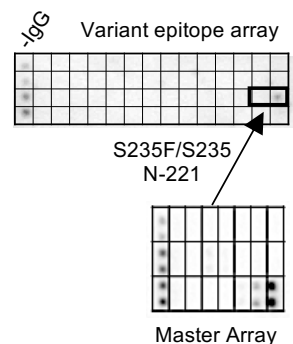

$\underline{\operatorname{cov}+88}$

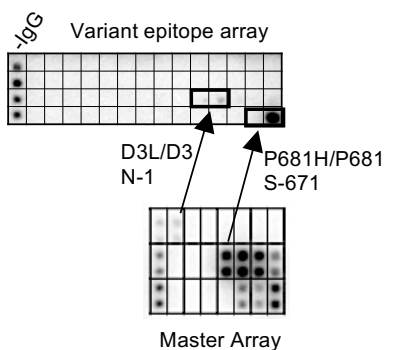

$\underline{\mathrm{COV}+14}$

C

Day 1

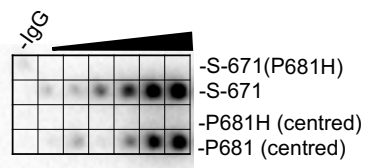

Day 2

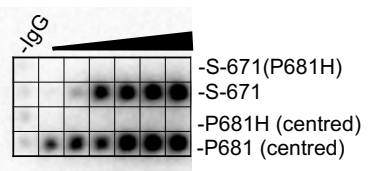

Day 3

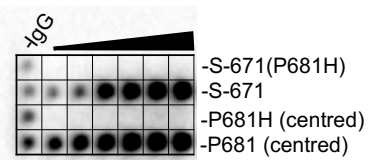

$\underline{\mathrm{COV}+14}$

Fig. 4. SARS-CoV-2 variants feature mutated epitopes not recognized by antibodies specific for the corresponding wt epitopes. (A) Layout of a SARS-CoV-2 variant epitope array. (B) Examples of COVID19 cases that showed distinct IgG responses to the mutated and wt epitopes (boxed). (C) Dilution series of $\mathrm{P} 681 / \mathrm{P} 681 \mathrm{H}$-containing epitopes demonstrating the loss of binding for the mutant epitopes. 

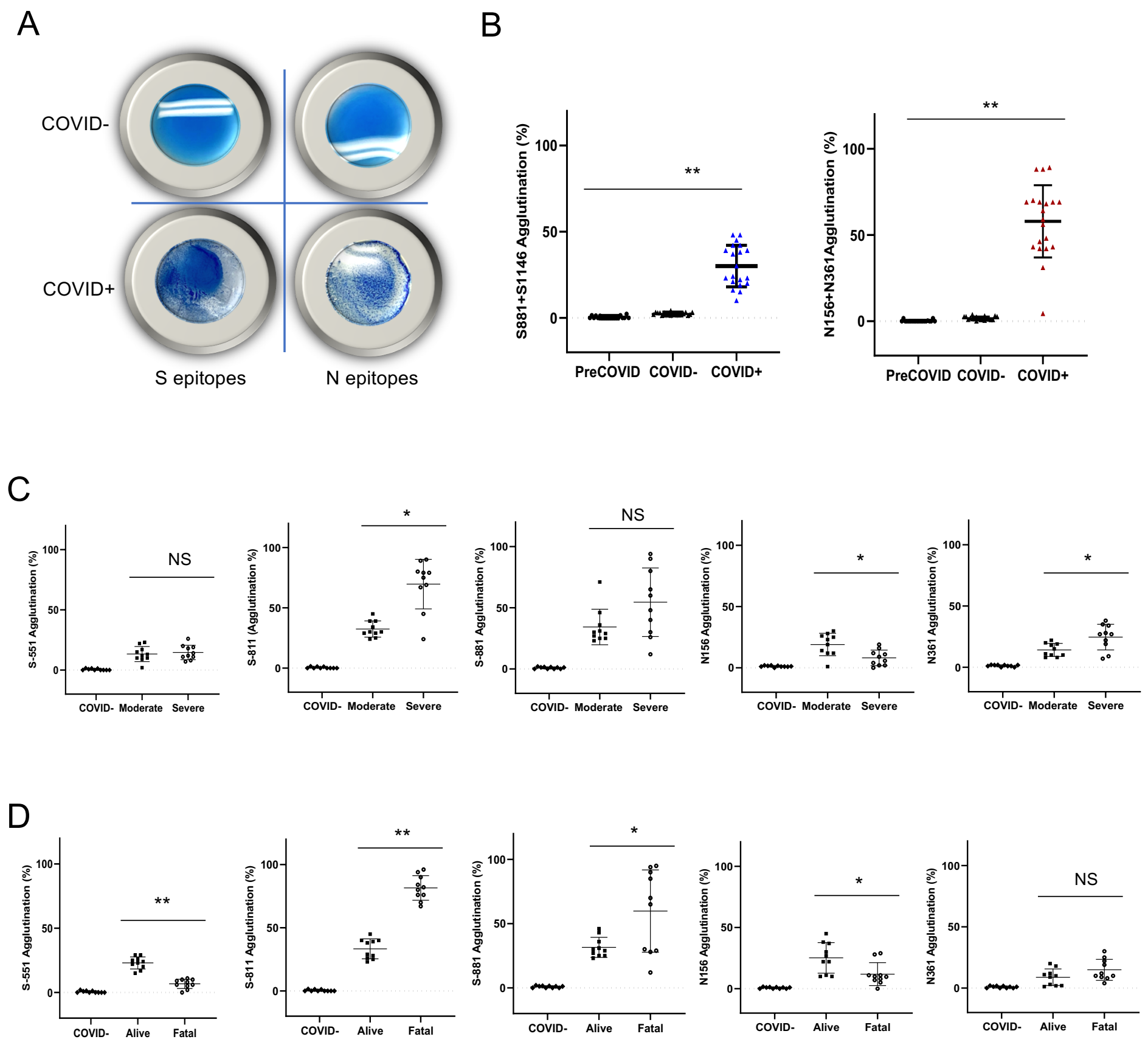

Fig. 5. Rapid epitope-dependent agglutination assay for SARS-CoV-2 antibodies effectively differentiate patient groups. (A) Latex bead agglutination assay to gauge antibody response to SARS-CoV2. The latex beads were coated with one or more biotinylated $S$ or $N$ epitope peptides and mixed with SARSCoV-2 -negative (COVID-, top) or -positive (COVID+, bottom) plasma. The presence of antibodies against the epitopes promoted the agglutination of the latex beads. Images shown were taken after 2 min incubation at room temperature. (B) Epitope-based latex agglutination assay distinguished COVID-19+ from COVID-19- or preCOVID-19 plasma. The epitope peptides used were: S-811 and S-1146 from the spike and N-156 and N361 from the nucleocapsid protein. (C) Correlation of disease severity with antibody responses to the S-811, $\mathrm{N}-156$ and $\mathrm{N}-361$ determined by latex bead agglutination. (D) Correlation of disease outcome with antibody responses to the S-551, S-811, S-881 and N-156 epitopes determined by latex bead agglutination. $P$ values calculated based on unpaired Student t-test with Welch's correction (no assumption of equal SD) ( $n=20$ for B; $n=10$ for $C \& D) .{ }^{*} p<0.05,{ }^{* *} p<0.002$. 
A
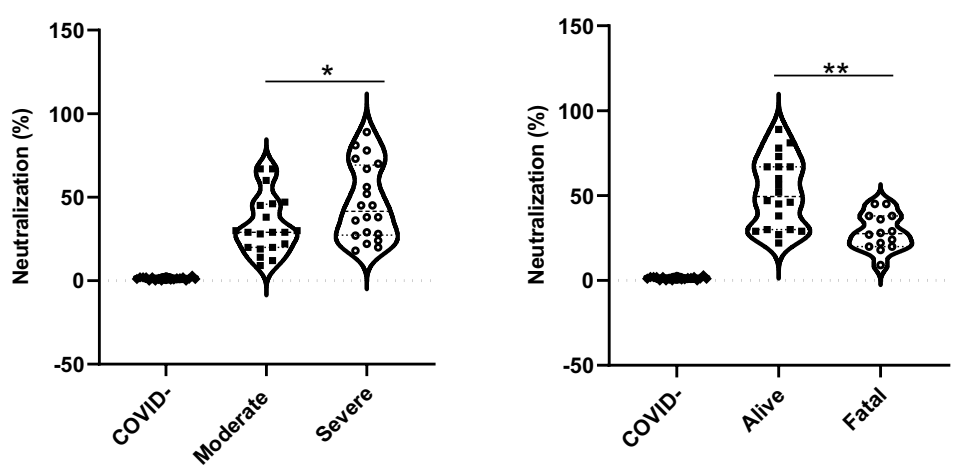

B
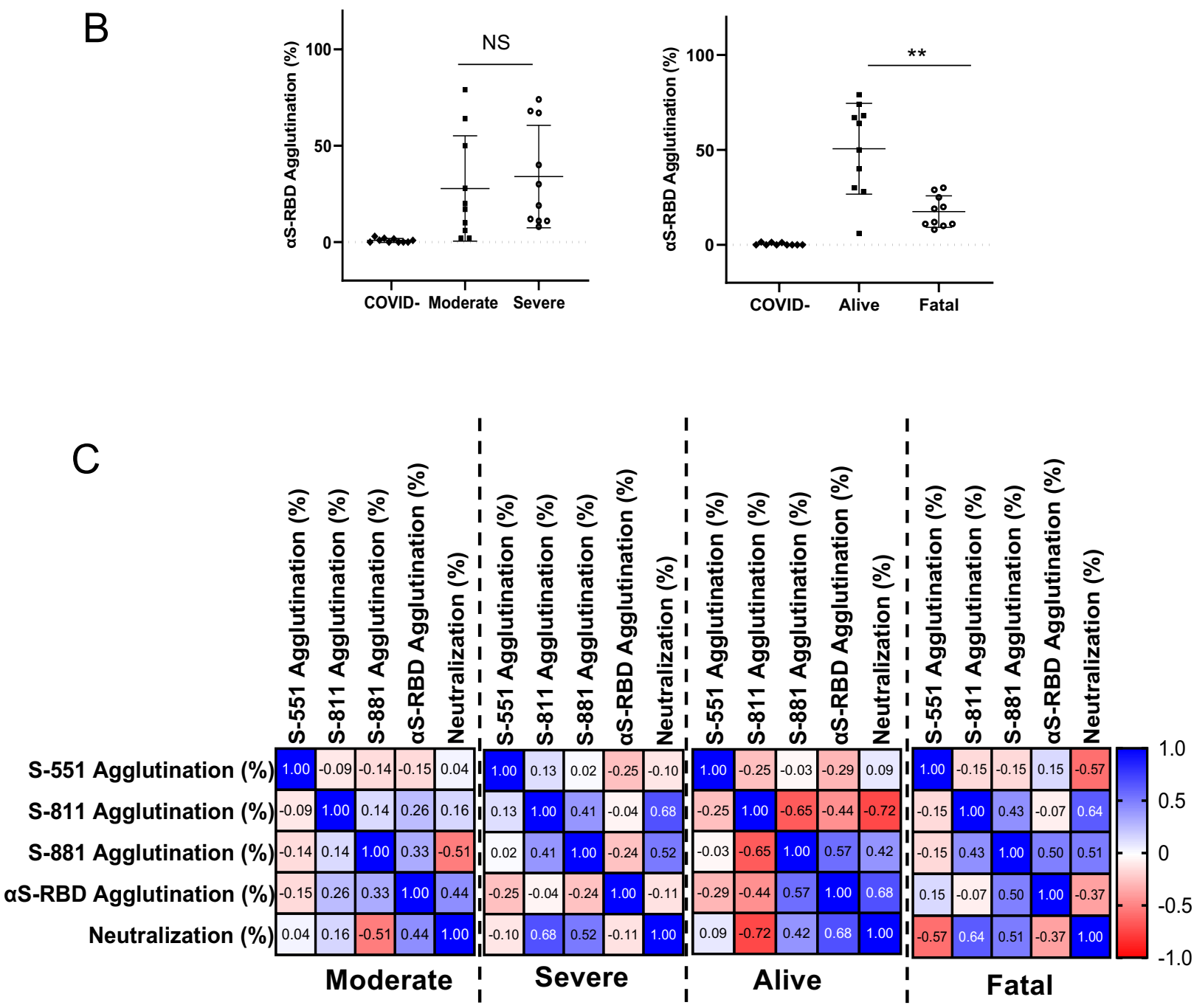

Fig. 6. Antibody specificity predicts neutralization efficiency and disease outcome. (A) Correlation of neutralization efficiency with clinical severity (left) or outcome (right). ${ }^{*}, p<0.05 ;{ }^{* *}, p<0.01$. (B) Correlation of S-RBD-antibody response measured by latex agglutination with COVID-19 severity (left) or outcome (right). ${ }^{* *}, p<0.01$. (C) Pearson ( $r$ ) correlation between epitope-dependent agglutination and neutralization. Confidence interval $(\mathrm{Cl})$ : $95 \%$. $P$ values were based on one-way ANOVA with Geisser-Green house correction (no assumption of equal variability of difference) ( $n=20$ for $A$, except $n=14$ for fatal; $n=10$ for $B \& C$ ). 